\title{
One Hundred Pressing Questions on the Future of Global Fish Migration Science, Conservation, and Policy
}

\section{OPEN ACCESS}

Edited by:

Nathan R. Senner,

University of South Carolina,

United States

Reviewed by:

Lucille Chapuis,

University of Exeter, United Kingdom Daniel Cardoso Carvalho,

Pontifícia Universidade Católica de Minas Gerais, Brazil

*Correspondence:

Robert J. Lennox

robertlennox9@gmail.com;

role@norceresearch.no

Specialty section:

This article was submitted to Behavioral and Evolutionary Ecology,

a section of the journal

Frontiers in Ecology and Evolution

Received: 29 March 2019

Accepted: 15 July 2019

Published: 19 August 2019

Citation

Lennox RJ, Paukert CP, Aarestrup K, Auger-Méthé $M$, Baumgartner $L$, Birnie-Gauvin K, Bøe K, Brink K,

Brownscombe JW, Chen Y, Davidsen JG, Eliason EJ, Filous A,

Gillanders BM, Helland IP, Horodysky AZ,

Januchowski-Hartley SR

Lowerre-Barbieri SK, Lucas MC,

Martins EG, Murchie KJ, Pompeu PS,

Power M, Raghavan R, Rahel FJ,

Secor D, Thiem JD, Thorstad EB, Ueda H, Whoriskey FG and Cooke SJ

(2019) One Hundred Pressing Questions on the Future of Global Fish Migration Science, Conservation, and

Policy. Front. Ecol. Evol. 7:286.

doi: 10.3389/fevo.2019.00286
Robert J. Lennox ${ }^{1 *}$, Craig P. Paukert ${ }^{2,3}$, Kim Aarestrup ${ }^{4}$, Marie Auger-Méthé ${ }^{5}$, Lee Baumgartner ${ }^{6}$, Kim Birnie-Gauvin ${ }^{4}$, Kristin Bøe ${ }^{7}$, Kerry Brink ${ }^{8,9}$, Jacob W. Brownscombe ${ }^{10,11}$, Yushun Chen ${ }^{12,13}$, Jan G. Davidsen ${ }^{14}$, Erika J. Eliason ${ }^{15}$, Alexander Filous ${ }^{16}$, Bronwyn M. Gillanders ${ }^{17}$, Ingeborg Palm Helland ${ }^{18}$, Andrij Z. Horodysky ${ }^{19}$, Stephanie R. Januchowski-Hartley ${ }^{20}$, Susan K. Lowerre-Barbieri ${ }^{21,22}$, Martyn C. Lucas ${ }^{23}$, Eduardo G. Martins ${ }^{24}$, Karen J. Murchie ${ }^{25}$, Paulo S. Pompeu ${ }^{26}$, Michael Power ${ }^{27}$, Rajeev Raghavan ${ }^{28,29}$, Frank J. Rahel ${ }^{30}$, David Secor ${ }^{31}$, Jason D. Thiem ${ }^{32}$, Eva B. Thorstad ${ }^{18}$, Hiroshi Ueda ${ }^{33}$, Frederick G. Whoriskey ${ }^{34}$ and Steven J. Cooke ${ }^{11}$

${ }^{1}$ Laboratory for Freshwater Ecology and Inland Fisheries, NORCE Norwegian Research Centre, Bergen, Norway, ${ }^{2}$ U.S. Geological Survey, Missouri Cooperative Fish and Wildlife Research Unit, Columbia, MA, United States, ${ }^{3}$ The School of Natural Resources, University of Missouri, Columbia, SC, United States, ${ }^{4}$ Section for Freshwater Fisheries and Ecology, Technical University of Denmark, Silkeborg, Denmark, ${ }^{5}$ Department of Statistics, Institute for the Oceans and Fisheries, The University of British Columbia, Vancouver, BC, Canada, ${ }^{6}$ Institute for Land, Water and Society, Charles Sturt University, Albury, NSW, Australia, ' Department of Ocean Sciences, Memorial University, St. John's, NL, Canada, ${ }^{8}$ World Fish Migration Foundation, Groningen, Netherlands, ${ }^{9}$ School of Life Sciences, College of Agriculture, Engineering and Science, University of KwaZulu-Natal, Pietermaritzburg, South Africa, ${ }^{10}$ Fish Ecology and Conservation Physiology Laboratory, Department of Biology, Carleton University, Ottawa, ON, Canada, ${ }^{11}$ Department of Biology, Dalhousie University, Halifax, NS, Canada, ${ }^{12}$ Institute of Hydrobiology and State Key Laboratory of Freshwater Ecology and Biotechnology, Chinese Academy of Sciences, Wuhan, China, ${ }^{13}$ University of Chinese Academy of Sciences, Beijing, China, ${ }^{14}$ Department of Natural History, NTNU University Museum, Trondheim, Norway, ${ }^{15}$ Department of Ecology, Evolution and Marine Biology, University of California, Santa Barbara, Santa Barbara, CA, United States, ${ }^{16}$ Department of Environmental Conservation, University of Massachusetts Amherst, Amherst, MA, United States, ${ }^{17}$ Environment Institute and School of Biological Sciences, University of Adelaide, Adelaide, SA, Australia, ${ }^{18}$ Norwegian Institute for Nature Research, Trondheim, Norway, ${ }^{19}$ Department of Marine and Environmental Science, Hampton University, Hampton, VA, United States, ${ }^{20}$ Department of Biosciences, Swansea University, Swansea, United Kingdom, ${ }^{21}$ Fisheries and Aquatic Science Program, School of Forest Resources and Conservation, University of Florida, Gainesville, FL, United States, ${ }^{22}$ Florida Fish and Wildlife Conservation Commission, Florida Fish and Wildlife Research Institute, St. Petersburg, FL, United States, ${ }^{23}$ Department of Biosciences, University of Durham, Durham, United Kingdom, ${ }^{24}$ Ecosystem Science and Management Program, University of Northern British Columbia, Prince George, BC, Canada, ${ }^{25}$ Daniel P. Haerther Center for Conservation and Research, John G. Shedd Aquarium, Chicago, IL, United States, ${ }^{26}$ Biology Department, University of Lavras, Lavras, Brazil, ${ }^{27}$ Department of Biology, University of Waterloo, Waterloo, ON, Canada, ${ }^{28}$ Department of Fisheries Resource Management, Kerala University of Fisheries and Ocean Studies (KUFOS), Kochi, India, ${ }^{29}$ Mahseer Trust, Freshwater Biological Association, Wareham, United Kingdom, ${ }^{30}$ Department of Zoology and Physiology, University of Wyoming, Laramie, WY, United States, ${ }^{31}$ Chesapeake Biological Laboratory, University of Maryland Center for Environmental Science, Cambridge, MD, United States, ${ }^{32}$ Department of Primary Industries, Narrandera Fisheries Centre, Narrandera, NSW, Australia, ${ }^{33}$ Field Science Center for Northern Biosphere, Hokkaido University, Hokkaido Aquaculture Promotion Cooperation, Sapporo, Japan,

${ }^{34}$ Ocean Tracking Network, Dalhousie University, Halifax, NS, Canada

Migration is a widespread but highly diverse component of many animal life histories. Fish migrate throughout the world's oceans, within lakes and rivers, and between the two realms, transporting matter, energy, and other species (e.g., microbes) across boundaries. Migration is therefore a process responsible for myriad ecosystem services. Many human populations depend on the presence of predictable migrations of fish for their subsistence and livelihoods. Although much research has focused on fish migration, many questions remain in our rapidly changing world. We assembled a 
diverse team of fundamental and applied scientists who study fish migrations in marine and freshwater environments to identify pressing unanswered questions. Our exercise revealed questions within themes related to understanding the migrating individual's internal state, navigational mechanisms, locomotor capabilities, external drivers of migration, the threats confronting migratory fish including climate change, and the role of migration. In addition, we identified key requirements for aquatic animal management, restoration, policy, and governance. Lessons revealed included the difficulties in generalizing among species and populations, and in understanding the levels of connectivity facilitated by migrating fishes. We conclude by identifying priority research needed for assuring a sustainable future for migratory fishes.

Keywords: ecosystem services, ichthyology, habitat connectivity, partial migration, conservation, ecology

\section{INTRODUCTION}

Migration is an adaptive and widely expressed behavior within the animal kingdom. Species' movements among habitats, whether by solitary individuals or as synchronized collective displacements by many animals, facilitate exploitation of patchy and seasonally variable resources, which is key to species' reproduction and persistence (Baker, 1978; Jørgensen et al., 2008). As the most speciose classes of vertebrates, fishes provide an excellent focal group for the study of the evolution and ecology of migration (Lucas and Baras, 2001). Among fishes, a taxonomy of migration types exist for species moving between, and within, marine and freshwater environments (e.g., diadromy, oceanodromy potamodromy; Myers, 1949).

Migration is ecologically important, but also a behavior that is under significant threat worldwide (Wilcove and Wikelski, 2008). Animal migrations connect ecosystems and transport matter and energy long distances-faster than would be conveyed by wind, currents, or tides. Carbon, nutrients, and pathogens carried in the bodies of migratory animals have been shown to make substantial contributions to recipient ecosystems (Naiman et al., 2002; Hall et al., 2012; Childress and McIntyre, 2015). Therefore, assuring secure pathways among habitats is essential to support migration; a key consideration for ecosystem management (Mumby, 2006; Fuller et al., 2015). Migratory species' reliance on multiple habitat types also increases their vulnerability to human disturbances such as fragmentation caused by dams, roads, or land use change, as well as climate change and other human-mediated global changes (Wilcove and Wikelski, 2008; Secor, 2015b). There have been an increasing number of studies to better our understanding of how different human disturbances influence and affect diverse migratory species. With increasing recognition of the importance of protecting migratory fish species, there have been rapid developments in our understanding of how these stressors operate and in the appropriate mitigations needed to limit their impacts on migratory fishes (Lucas and Baras, 2001; Brink et al., 2018; Lowerre-Barbieri et al., 2019).

Despite a growing number of studies, there remains a need to identify knowledge gaps as well as plan a research agenda based on focused questions related to understanding and conserving migratory species. The goal of our paper is to identify 100 outstanding questions about the mechanisms and processes of fish migration, and human disturbances that threaten migratory species' persistence (see Figure $\mathbf{1}$ for an overview of related topics and considerations). Our questions encompass fish species across habitats, ecologies, and taxa. We identify timely and relevant questions that, if addressed, will advance our understanding of which fish species migrate, how, when, and why they do so, and the actions required to conserve these species and the habitats that they depend on. We present nine broad themes relevant to fish migration, beginning each theme with a brief description, followed by a series of related questions to be explored. We conclude with a proposed research agenda for migratory fishes, giving emphasis to the science that has the potential to inform management and policy actions.

\section{ONE HUNDRED QUESTIONS}

Each author of this paper independently derived a series of questions about fish migration and shared them with the first author. Questions were then sorted into themes using the movement ecology framework from Nathan et al. (2008) that integrates internal and external drivers, navigation, and motion capacity as fundamentals of animal movement. The questions we identified relate to animal internal state (energetics, drivers, endocrinology); navigation (orientation and timing); locomotion; external drivers of migration; threats to fish migration related and unrelated to climate change, as well as environmental conservation; policy and governance related to migratory fishes, and thematic questions on the role of migration (Figure 1). Breakout groups around each theme synthesized and refined related questions. We present the nine themes and related questions below.

\section{Internal State}

A fish's internal state and its maintenance of homeostasis are regulated by a combination of abiotic and biotic stimuli, as well as interactions with genetics, morphology, life history, cognition, and physiology (Uusi-Heikkilä et al., 2008). Individual and collective behavior ultimately feed back to influence internal state, meaning that migration itself can influence the internal 


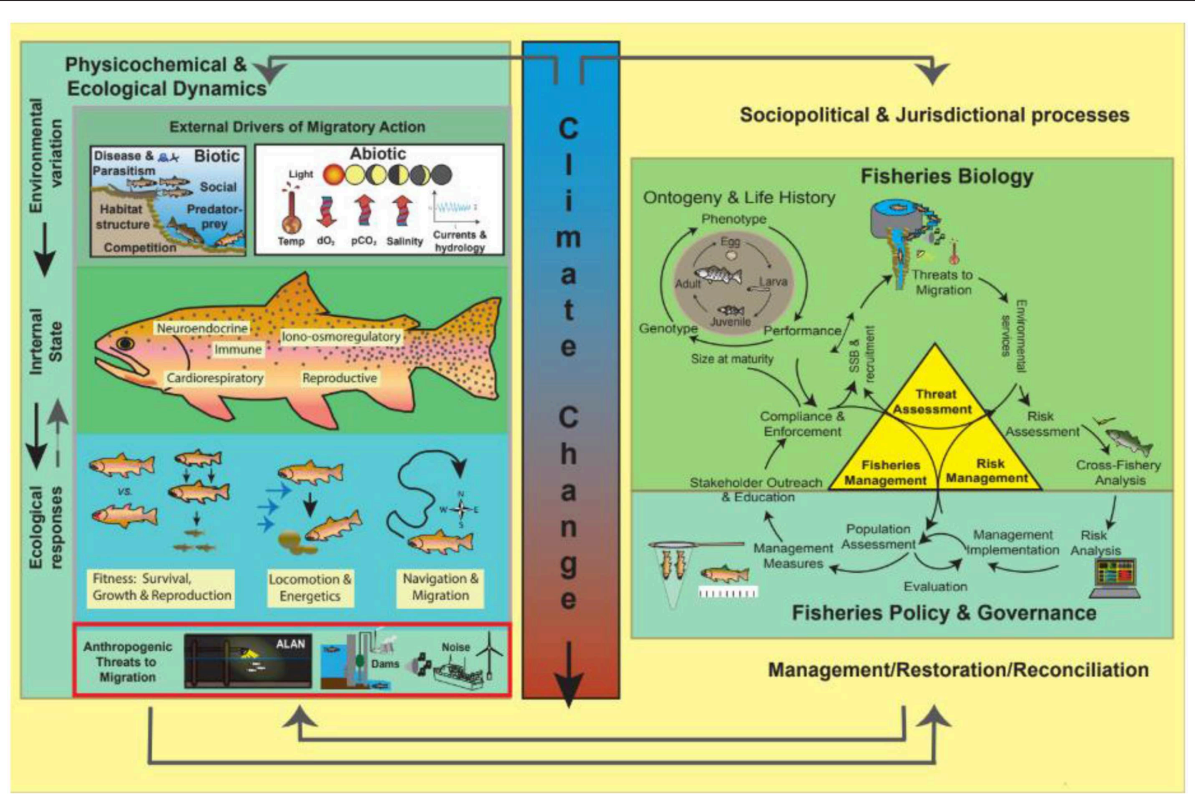

FIGURE 1 | By migrating, a fish uses multiple habitats for growth, refuge and reproduction. External drivers such as lunar and solar cues and temperature are integrated by fish sensory systems and can shift the internal state, stimulating migration. Fish use multiple physiological sensory systems to navigate and arrive at the right place at the right time and conserve energy with efficient locomotion. Many migratory fish taxa are threatened by human infrastructure and land use modification, which can interact with threats posed by climate change. In the right-hand panel, we see how sociopolitical and jurisdictional processes can affect the environmental aspects of migration. Threats to migratory fish are managed, often through fisheries management, and risks are managed with other institutions such as marine protected areas. Rapid environmental change from climate change or human activities affect the relationship between cues and environmental conditions, which mismatches migratory timing and energy budgets and can threaten the viability of migration as a behavior. Governance structures and political institutions are responsible for minimizing these threats and implementing effective management actions, including habitat restoration that maintains connectivity and ensures migratory fish will persist in the future. ALAN refers to artificial light at night.

state and that internal state can in turn influence migration. For example, recent evidence suggests that stress levels and nutritional status can both impact migration distance and success in salmonids (Bordeleau et al., 2018; Birnie-Gauvin et al., 2019a). Few such studies exist, but these can shed light on the mechanistic links between internal state and migratory behavior. These synergies are especially important given ecological consequences of recent human-mediated trait changes to fish populations (Jørgensen et al., 2007; Palkovacs et al., 2012; Rahel and McLaughlin, 2018). Understanding the effects of ecosystemorganism interactions on short-term movements and longerterm migrations of fishes requires approaches that unify: a) mechanistically-driven physiological studies, b) patternoriented behavioral studies, and c) quantitatively driven fisheries sciences (Horodysky et al., 2015). Quantifying the internal state of the animal from non-lethal biopsy of blood, gill, or other tissues can allow subsequent movement patterns to be ascertained through laboratory experiments or in the field using biotelemetry for remote monitoring. These methods can advance our understanding of mechanistic linkages between hormone levels, gene expression, or other internal variables and the movement patterns exhibited by the individual. Below, we provide a series of questions to guide future inquiry into the effects of fish internal state on movement and migration:
1. What are the internal physiological drivers of, and triggers for, migration?

2. Is ontogeny an important factor regulating migratory strategies?

3. What role do genetics and epigenetics have in migration?

4. Are migratory phenotypes (residents, short-distance migrants, long-distance migrants) reflected in physiological phenotypes (predictable differences in metabolic rate, condition, energetic state, proteomics, etc.)?

5. Can physiological indices (e.g., gene expression, endocrine stress, oxidative stress, osmoregulation, sensory modalities) be used to predict migration success?

6. How can nutrition or available energy limit migration ability, either directly or indirectly?

7. What is the role of the neuroendocrine system on migration?

8. How can we characterize internal drive to migrate, and what internal factors are involved?

9. What are the costs of migration to an animal's internal state and physiology (e.g., energetics, oxidative stress, carryover effects)?

10. Do physiological processes (e.g., up/down regulation of gene expression, endocrinology) differ between when animals depart and return to natal habitats?

11. How do disease, infections, and parasites affect fish internal state during migration-related processes? 
12. Do multiple stressors have additive or synergistic effects on migratory behavior?

13. To what extent are migration strategies heritable?

14. Can physiological processes that stimulate migration be used to inform conservation and management?

15. What causes a fish to lose the drive to migrate (i.e., stop migrating, spawn at a suboptimal location due to a barrier, stray to a different area than intended), including intergenerational changes caused by selection (e.g., changes to migration routes)?

16. How common are movement syndromes in fish (i.e., what distinguishes animals that migrate and those that do not) and what drives these at the individual scale?

17. What physiological changes at the population scale lead to irruptions and/or colonization events (i.e., straying at a large scale to expand or shift the population distribution)?

\section{Navigation}

Fish species migrate variable distances among habitats (Lohmann et al., 2008). Wayfinding mechanisms within fishes typically depend on the extent of their migration and vary with species, life stages, and environments (Ueda et al., 1998; Ueda, 2018). Magnetic senses likely play a role in the navigation of many species (Durif et al., 2013; Putman et al., 2014) along with olfactory and visual cues (Ueda et al., 1998) and learning (Dodson, 1988; Brown and Laland, 2003). Fish populations, and in some cases species, have evolved different spatial strategies through natural selection: some have high degrees of philopatry, whereas others exhibit substantial plasticity in their movement and migration behaviors (Secor, 2015a). This phenomenon needs further detailed exploration using comparative and experimental approaches. Timing, route efficiency, and accuracy of migration are critical for fish species to arrive at their destination at the right time and with sufficient energy reserves (Cooke et al., 2006), and dispersal to new areas is also critical for population resilience, gene flow (Klemetsen, 2010), and for recolonization (Perrier et al., 2009; Radinger and Wolter, 2014). Tracking technology has allowed us to elucidate the onset, periodicity, and progress of some migrations; although many fishes are too small to be tagged this way with the size of current technology. Despite an increasing number of studies on a broader diversity of fish species (i.e., beyond salmonids) and migration types, our understanding of how different species find their way and what can affect their navigation remains limited. These limitations in knowledge influence our ability to manage or conserve species and the habitats that they depend on. We propose that key research questions for future work in the navigation theme are:

18. How do the Earth's rapidly shifting magnetic field and increasing anthropogenic electromagnetic fields affect fish migration?

19. How do hydrodynamic conditions (e.g., turbulence, flow rate, currents) influence migratory fish navigation?

20. How spatially and temporally accurate, and precise, is the homing of different migratory fish taxa?
21. How many different mechanisms are used among fish species, and concurrently within a given species, to navigate to the correct place?

22. What is the role of intraspecific variation in migration timing to individual success relative to population persistence?

23. What is the role of dispersal as a component of migration or an alternative to migration?

24. How does artificial light at night affect navigation of fishes, especially in coastal areas?

25. Does anthropogenic noise affect the distribution of fish and their ability to navigate?

\section{Locomotion}

Migratory fish exhibit extreme variability in their modes of locomotion, from the highly maneuverable Anguilliformes to the streamlined Thunniformes that can sustain fast swimming speeds (Sfakiotakis et al., 1999). Within a population, individuals can also vary significantly in their locomotor abilities (Reidy et al., 2000). For migratory animals, swimming capacity is often an important factor influencing success as it determines an individual's ability to pass natural and human-made barriers or surmount other challenges (Hinch and Bratty, 2000; Cooke et al., 2006). Understanding locomotion can be critical for maintaining suitable conditions for fish to migrate in habitats where humans have some degree of control over the physical environment, for example in rivers where water levels or flows are regulated and effective fish passage infrastructure may or may not have been built. Migrations can be energetically costly; therefore, efficient and judicious use of energy stores can also affect migration success (Brownscombe et al., 2017). Human activities are rapidly changing the environmental conditions in ways that challenge the physical and metabolic capabilities that fish rely upon to power themselves to their destinations (Lucas and Baras, 2001). With the existence of such variability in fish locomotory modes, abilities, migratory types, and challenges, and alterations to the environmental conditions both on and off migration routes, human-induced environmental change will generate varied and in some cases unanticipated responses amongst migratory fishes. The questions posed in this theme address key knowledge gaps relevant to how various fish species and ecosystems will be affected.

26. In which ecological contexts (e.g., group size, parasite load) do individual variation in locomotory ability influence the ability to successfully migrate?

27. What are the main physical, behavioral, and ecological drivers of swimming performance?

28. Are changes to environmental conditions (e.g., temperature, oxygen) and migratory obstacles (e.g., dams, currents) disproportionately affecting fish with specific swimming modes, physical characteristics, or life histories?

29. How will changes to ocean currents and river flows affect the migratory performance of species with different locomotor performance and larval recruitment dynamics?

30. Will human-induced changes to fish life history (e.g., changes in size-at-age of maturity due to size 
selective fishing) affect the locomotor performance of migratory species?

31. In which ecological contexts are efficient movements (e.g., least cost paths, energetically efficient swimming speeds) relevant to migration success?

32. Which characteristics of swimming performance explain the reliance of certain species on least cost paths for migration success?

33. What role does voluntary movement have on migration success of larval fish that are mostly conveyed by currents (e.g., eel leptocephalus larvae)?

\section{External Drivers}

External drivers, along with a fish's internal state, stimulate behaviors including movement and habitat shifts to important foraging or spawning grounds that maintain or restore individual homeostasis and satisfy life history demands. Fish migrations must be properly timed on short (e.g., diurnal) and long (e.g., seasonal) timescales to optimize the balance between costs (avoiding hostile conditions) and benefits (matching distributions to abundant feeding opportunities) to maximize fitness (Dingle and Drake, 2007). Decisions to migrate or not, and when to migrate, are often regulated by abiotic external drivers (e.g., day length; Bradshaw and Holzapfel, 2007). External cues can regulate long-term physiological and morphological developments that prepare fishes for arrival into new environments, and can synchronize groups of fish to migrate under favorable conditions (e.g., lunar phases). Human disturbances, such as noise, artificial light, and dam discharge can also influence decisions to migrate, and potentially also alter timing and route choice (Reid et al., 2019). By understanding how external drivers interact with fish internal states, and how these can regulate migration, we can develop more effective actions and policies to mitigate impacts on migratory species (Bowlin et al., 2010). Key questions about the role of external drivers upon fish migration include:

34. How many different abiotic external drivers inform migratory fish behavior and how do they interact?

35. What environmental thresholds exist that initiate partial and facultative migration, and how do these influence the likelihood of migration?

36. Do climatic differences along geographic clines (e.g., latitude) influence migratory phenotypes; if so, is the variation predictable or generalizable among species (e.g., differences in timing or extent of migration)?

37. To what extent are external drivers conflicting with rapidly changing environmental conditions that influence migration success?

38. What role do migrant densities have in regulating migratory species' population dynamics (e.g., functional and numerical responses of predators)?

39. How do host-pathogen dynamics contribute to the evolution of migration?

40. How does land use change affect the delivery of accurate cues for migrating fishes?
41. To what extent do changes to habitat quality override spawning site fidelity, informing fish to abandon their destination habitat for more suitable habitat?

42. How do invasive species that affect relevant food abundances influence native fish migration?

43. How does hypoxia (seasonal and otherwise) affect the energetics, movements, and geographic distributions of migratory fishes?

44. What is the relationship between schooling and migration behaviors?

\section{Threats (Excluding Climate Change)}

Humans aggregate around water (Fang and Jawitz, 2019) and use rivers, lakes, and oceans for drinking water, producing food, wastewater treatment, transport and trade, and in many other ways that modify or threaten the ecological integrity of these systems (Halpern et al., 2008; Vörösmarty et al., 2010; Reid et al., 2019). Chemical pollution (Hellström et al., 2016), artificial light (Longcore and Rich, 2004), noise (Filous et al., 2017), water abstraction (Benstead et al., 1999), barrier installation (Silva et al., 2018), and fishing (Jørgensen et al., 2008) all affect or have the potential to affect fish migrations. Our understanding of impacts on migratory fishes by different human disturbances is often confined to shorter-term effects (e.g., one migration cycle) and single disturbances, but we must move to evaluate the effects of disturbances across longer time periods (e.g., intergenerational impacts), and to evaluate cumulative interactions among the many human disturbances that confront different migratory fish species. Important future research questions about threats are:

45. What is the relative impact of different types of aquatic barriers and infrastructure on fish migration patterns and survival?

46. What are the individual and cumulative effects of anthropogenic stressors (e.g., water quantity/quality, sedimentation, anthropogenic sound and light) on physiology and ecology of migratory species and how can we mitigate these threats?

47. How do capture fisheries (recreational, subsistence, and commercial) that may remove migratory fishes and/or their prey affect the distribution and abundance of migrating fishes (both immediately and in terms of artificial selection on population traits)?

48. What existing or emerging chemical pollutants have the potential to affect fish migration and how?

49. Does sea cage aquaculture alter wild-fish migrations by providing resource subsidies or by aggregating prey fish that migrants rely upon?

\section{Threats From Climate Change}

Human mediated climate change is establishing a future that will be characterized by temperature extremes, evaporative water losses, and more variable timing and extent of precipitation, as well as surface water levels and flow, salinity, and temperature (Alexander et al., 2006; Hoegh-Guldberg and Bruno, 2010). These changes are altering community phenology, species dynamics, and distributions (Walther et al., 2002; Lynch et al., 
2016). Climate change is also altering pathogen dynamics, the impacts of which are poorly understood with respect to fish migration (Miller et al., 2014; Vollset et al., 2016). Migratory species are disproportionately influenced by these ongoing global changes compared to resident species because of their reliance on multiple geographically separated habitats that are changing at different rates and in different ways (Both and Visser, 2001; Robinson et al., 2009). For example, multiple mismatches could develop in relation to food availability and migration, including temporal mismatch from fish using traditional drivers of migration to pursue movements, but where the drivers are no longer linked to favorable conditions along the migration route, and spatial mismatch if fish move to foraging grounds that are no longer productive (Free et al., 2019). On the same note, migratory species' abilities to move, especially long distances, could buffer such effects of change, because behavior is the fastest route available for species to cope with change (Lehodey et al., 2006; Chessman, 2013). Finally, climate change can interact with other disturbances such as fishing (Ottersen et al., 2010) and dams (Secor, 2015b), and there remains a need to explore these interactions and effects on different migratory species. Key questions related to the impact of climate change upon migratory fishes are:

50. How much can/will fishes behaviorally adapt (e.g., alter the timing or nature of their migration) to cope with environmental changes?

51. Are hypoxia, hyperthermia, or other climate-associated stressors affecting the distribution (e.g., prey availability), quality (e.g., energetic content), and access to critical resources needed by migratory fishes?

52. How are changes in water temperature, acidity, and flow, as mediated by global climate change, affecting fish sensory systems and the role they play in different fish species abilities to navigate?

53. Can related or potential surrogate species be used to infer the degree to which migration patterns have changed for key commercial or valued species?

54. How do pathogens affect fish migration and are the effects more pronounced under regimes of acute or chronic environmental change?

55. Will altered migration patterns of species due to climate change result in global net increases or decreases in migratory fish production?

56. Will lower latitude regions lose migratory fish species and production more quickly or disproportionately as compared with higher latitude regions?

57. Will any regions show positive increases in fish production based on the arrival of new migrants?

58. How, if at all, is climate-mediated changing floodplain inundation affecting the recruitment of different migratory fishes?

59. Are altered environmental conditions from climate change (e.g., ocean circulation, sea levels, ice cover extent and duration) creating new, and potentially persistent, migration pathways?
60. What will be the role of fish migration in influencing how existing and new fish diseases spread and proliferate under human-mediated climate change and what are the consequences for populations at range edges?

61. How do fish respond to implemented environmental flows as mitigation measures and how does fish passage infrastructure need to consider changes in climate to maintain environmental flows?

62. What measures are needed to ensure the presence of secure movement pathways for migratory aquatic species in the face of climate change?

\section{Conservation Management}

The management of fish migrations developed primarily to restore the free movement of fishes in systems fragmented by dams and other in-stream infrastructure (McLaughin et al., 2013). Early efforts to provide passage at dams included royal decrees to remove weirs from salmon rivers in the Magna Carta $(1215)^{1}$ and the installation of fish ladders in Europe in the 1800s (Orsborn, 1987). Efforts to consider passage of all species are needed to ensure ecosystem-scale conservation of migratory fish species in impacted rivers, including successful downstream passage by the young of anadromous species and the adults of catadromous species such as freshwater eels (Anguillidae; Roscoe and Hinch, 2010). Selective fish passage systems that exploit species differences in physical ability, spawning behavior, and sensitivity to various sensory stimuli are the object of much current research (Birnie-Gauvin et al., 2018; Rahel and McLaughlin, 2018; Silva et al., 2018). Efforts also exist to re-connect rivers and processes such as sediment transport to riparian zones (Hauer et al., 2018; Hohensinner et al., 2018). Similar approaches could be explored for use in marine environments used by migratory species. For example, Murchie et al. (2015) found bonefish (Albula spp.) selected a manufactured canal as a migration route to access spawning grounds, in lieu of a historical natural corridor. Expanding beyond fishways as tools for assisting fishes over built infrastructure, there remains a need to further explore complementary management actions such as temporal protected zones (see Abell et al., 2007), designating protected species, regulating habitat loss and pollution, monitoring and managing exploitation, and gearuse restrictions for fisheries. Spatial planning efforts benefit from an understanding of the resource selection, distribution, and movements of migratory species that can be disturbed by human activity (Lennox et al., 2018a). We explore key questions related to conservation management below. Key conservation and management questions relevant to migratory fishes are:

63. Is there a key time window in which habitat connectivity needs to be restored before population rebounds can occur in migratory species?

64. How do the management strategies of: maximizing adult returns, maximizing juvenile out-migration, and

\footnotetext{
${ }^{1}$ see section 33; originally published 1215. Available online at: https://www. constitution.org/eng/magnacar.htm (accessed July 27, 2019).
} 
preserving spawning habitat compare in their performance as management objectives with regards to desirable population outcomes?

65. Can protection of "umbrella species" (i.e., those whose protection affords benefits to others) be used to promote conservation of both migratory and non-migratory species (that may still disperse at least locally among habitat patches)?

66. How can we apply existing knowledge, and mobilize new knowledge, to effectively mitigate threats with limited funding and opportunities?

67. How can stock assessment methods adapt to the changing behavior (e.g., timing, distribution) of migratory fishes?

68. How can intraspecific variation in migratory behavior be incorporated into management models?

69. To what extent are artificial habitats, such as reservoirs, mortality sinks for migrating fishes and how can such mortality be minimized?

70. How effective is habitat restoration, including dam removal and fishway installation, and how can we accurately evaluate the costs and benefits to make better decisions?

71. How can we balance the potential for invasive species introductions with connectivity restoration for migratory species?

72. Can fishways perform as well as dam removal?

73. Can we design fish passage systems that facilitate passage by desirable species while blocking or reducing passage by undesirable (often non-native) species?

74. How can attractive (sex pheromones, larval pheromones) and repulsive (necromones) scents be used to attract migrating fish to desired migration pathways or repel them from undesired pathways or block the movements of invasive species?

75. How does the level of protection of intermittent headwater streams, hydrologically connected wetlands, and floodplains affect migratory fishes?

76. At what scale would the establishment of free-flowing rivers as conservation units protect migratory species in highly diverse river systems?

77. How do we integrate migratory processes affecting vulnerability into fisheries stock assessments or harvest control rules?

\section{Policy and Governance}

Policy instruments and governance structures are fundamental to the development, implementation, and enforcement of regulations of sustainable management action and protection of nature (Gunningham et al., 1998; Lange et al., 2013). This is particularly salient for migratory organisms. As noted at the start of this paper, migratory species routinely cross ecosystem boundaries, habitats, and jurisdictions at national and international scales (Shuter et al., 2010; Cooke et al., 2012; Runge et al., 2014), which can raise challenges for policy making and management (Link et al., 2011). Because many migratory species aggregate in migratory corridors or on their spawning grounds, they are also vulnerable to spatially explicit stressors including targeted fishing, red tides, and anthropogenic disturbances such as dams, weirs, and roads (Januchowski-Hartley et al., 2013; Lascelles et al., 2014). Consequently, effective policy and governance of migratory fishes often necessitates multiple government sectors working together, such as fisheries and those that deal with energy and water resource management (see Nieminen et al., 2017). It is also established that political will to enact policy that benefits the environment (including migratory fish) depends on an engaged and vocal public (i.e., the electorate; Chhatre and Saberwal, 2005). With regards to migratory fishes, these considerations raise the following questions:

78. At what spatial and temporal scales should policies and fisheries management function to effectively mitigate threats to all migratory species?

79. How can we implement an ecosystem approach to management when migrations cross geopolitical and ecosystem boundaries?

80. What type of international policies or institutions are needed to effectively manage migratory species?

81. Are existing structures and policy instruments for managing migratory fishes enough given the multitude of threats faced by such organisms?

82. How can fisheries and conservation management systems become more responsive to changes in distributions of stocks and their connectivity?

83. What policies and governance structures could be instituted to align with global best practices for migratory fish protection and management?

84. What is the balance of evidence and action (i.e., science vs. policy) needed to effectively manage migratory fishes-or, more specifically, at what point do we know enough such that enough research has been conducted and corresponding action is needed more than new information?

85. What narratives exist to engage the public in the conservation of migratory fish and their habitats?

86. How can we raise the profile of economically or culturally less significant species with more cryptic migrations?

87. How do we improve data availability and research on migratory fishes in low income countries (e.g., Malawi, Burundi, Niger, Madagascar)?

88. Because fish migrations can span broad temporal and spatial scales and cross many jurisdictional boundaries, what mechanisms for data sharing exist or can be developed?

\section{The Role of Migration}

One of the great challenges that emerges when discussing fish migration is establishing effective definitions for a process that is highly flexible. We know that many fish species are migratory, but without agreed upon definitions of what is a migration it can be difficult to identify which ones are not. Unknowns related to the ecological function of migration, for example, are challenging to unravel and we are in the early stages of identifying what role fish movements play in connecting environments, conveying carbon and nutrients, and transferring pathogenic and parasitic species (Altizer et al., 2011; Hyndes et al., 2014). Moreover, this yields further questions about the genetic consequences of migration and how to define species/populations as management units and 
assign responsibility for fish that cross boundaries (Dionne et al., 2008; Riccioni et al., 2010; Zeng et al., 2019). Methodological advances and new technologies may emerge to assist in answering some of these overarching questions in fish migration that will assist with addressing other, finer scale questions dealing with mechanisms. Questions about the role of migration are:

89. What is the evolutionary history and phylogeny of migration; is it an ancestral trait of animals or fishes that is not expressed in some species, or has it evolved independently many times?

90. How common is migration in fishes (i.e., how many and which fish species migrate)?

91. To what extent do small-bodied fishes migrate and, for those that do, how far and when?

92. How are migrating fishes structured into genetically distinct populations or evolutionarily significant units?

93. How common is vertical migration and what are its similarities and differences with other types of migration?

94. How many distinct typologies of migration are there and how can they be distinguished with respect to their ecological functions?

95. How can genetic, genomic, and chemical tags be used to assist with studying migration?

96. How tightly does fish migration couple ecological processes, both within the aquatic realm and between the aquatic and terrestrial realms, by moving matter and energy?

97. How important is intraspecific variation in migratory phenotypes (e.g., timing, frequency, body size) of migration?

98. How plastic is migration within genotypes, phenotypes, and species?

99. What role does migration have in the carbon cycle and carbon sequestration and how do threats such as barriers affect fish roles in carbon sequestration?

100. How can innovations in technology and engineering contribute new tools to answer questions related to fish migration?

\section{SYNTHESIS}

Failure to understand how, why, when, and where different fishes migrate, and the consequences of migration, limits our understanding of migratory fishes and their roles in aquatic and terrestrial ecosystems. Migration is a process occurring across different spatial and temporal scales, which has many implications for understanding how species, populations, communities, and ecosystems are structured and how they interact with one another. Understanding movements is critical to determining the resource requirements of species and identifying appropriate measures for protection (Lennox et al., 2018a). Here, we worked to identify outstanding questions about migratory fish species that could provide important knowledge about these species, and support guidance for the conservation of these species. Applying the movement ecology paradigm (Nathan et al., 2008) to engage scientists from fish ecology, physiology, evolution, behavior, and environmental conservation and management yielded a diverse set of questions that will better our understanding of migratory fishes, and provide evidence and knowledge needed to guide more effective conservation decisions for these species.

It can be challenging to evaluate how preservation, restoration, or degradation related to a migratory species' habitat can also affect the broader ecosystem, including human dependencies and economic activity (see Box 1 for some examples). A complete understanding of the diversity and functional ecology of migratory fishes is essential to making effective conservation and management decisions (LowerreBarbieri et al., 2019). Migration research has expanded in recent decades with increased access and application of technologies such as electronic tags, chemical and molecular tracers, acoustic imaging, telecommunications, and bioinformatics (Secor, 2015a; Lowerre-Barbieri et al., 2019). The number of taxa investigated is also expanding (see Box 1) and movement ecology is increasingly integrated within hydro-ecology, oceanography, and fisheries and habitat management (Hidalgo et al., 2016; Birnie-Gauvin et al., 2019b) to begin addressing fundamental questions related to migratory fish ecology and conservation. Applying the movement ecology paradigm to engage scientists from fish ecology, physiology, evolution, behavior, and environmental conservation and management yielded a strong list of questions that if answered will transform our understanding of migratory fishes and lead to better management of these species.

Genetic studies focused on the evolution of migration are needed to understand the underlying architecture resulting in variation between migratory and non-migratory species, as well as within and among migratory species (Hendry et al., 2000; Kess et al., 2019). Many species are partially migratory, having the genetic disposition to express migration depending on the environmental conditions that they experience (Olsson et al., 2006). Migratory phenotypes can respond over generations to selective pressures of the environment (Bracken et al., 2015). Rainbow trout and steelhead (Oncorhynchus mykiss), for example, are genetically the same species but with different migratory life histories and the migratory and non-migratory forms frequently coexist in coastal streams (Hecht et al., 2015). Understanding partial migration is key to unlocking information about migratory species (Pulido, 2011) and migratory behavior of hybrids can reveal how genetics and the environment contribute to migration (Kovach et al., 2015). Within migratory species, there is variation in the spatial and temporal extents of migratory behavior exhibited by individuals; Prince et al. (2017), for example, recently isolated a gene in steelhead, associated with early arrival to freshwater. Protecting genetic diversity within migratory species must be a priority given that this diversity underlies behavioral and physiological diversity that confers resilience to species. It has been increasingly demonstrated that habitat fragmentation and migration obstacles significantly, and rapidly, negatively affect biodiversity (So et al., 2006). A better understanding of how genetic isolation of distinct spawning stocks, and the phenotypic adaptations arising as a result (e.g., body shape, metabolic capabilities), is central to directing conservation efforts (e.g., Eliason et al., 2011). In turn, this 
BOX 1 | Cartilaginous and bony fishes from many different families exhibit migrations within, and between, lakes, rivers, and oceans. Migrations have significant ecological importance but many are poorly understood, hindering our comprehension of ecosystem functioning and our ability to conserve fish species or any associated services or values. Here we highlight some migratory fish species from around the world and refer to how answering lingering questions about their migrations should be a priority for scientists and management groups.

Bonefish are culturally and economically important coastal species that undertake spawning migrations from their neritic foraging habitats offshore to pelagic waters (Adams and Cooke, 2015). Acoustic telemetry revealed that at Anaa Atoll, French Polynesia, nearly all spawning movements of shortjaw bonefish (Albula glossodonta) occurred in two passageways on the northern end of the island where most artisanal fish traps are located (Filous et al., Unpublished Data). Movements were synchronized with the lunar cycle, but at different phases than Atlantic Albula vulpes. Although the neritic movements were well-characterized by telemetry, offshore movements remain an enigma. Additional research is needed to identify critical spawning sites and ensure that they remain unimpacted by anthropogenic development and their fisheries can be managed. It is also crucial to the understanding of larval dispersal and metapopulation connectivity. Transfer rate among populations, navigational mechanisms, and interspecific differences are critical to better understand these migrations (photo: Filous).

The Japanese grenadier anchovy Coilia nasus migrates from the Yangtze River estuary up the Yangtze River and its adjacent lakes for spawning and growth (Dou et al., 2012). Dams and sluice gates have blocked key migration routes and other human stressors such as navigation and channel modifications and overfishing have caused dramatic habitat loss for this fish species (Xue et al., 2019). Understanding locomotor capabilities of this species may be necessary to determine if they can pass sluice gates to adjacent lakes, spawn and grow successfully. Investigating internal and external drivers will also assist in predicting migration and preparing to open gates to facilitate passage. Tracking studies are also needed in order to identify how habitat requirements change with ontogenetic stage and determine whether suitable habitat can be preserved or created (photo: Chen).
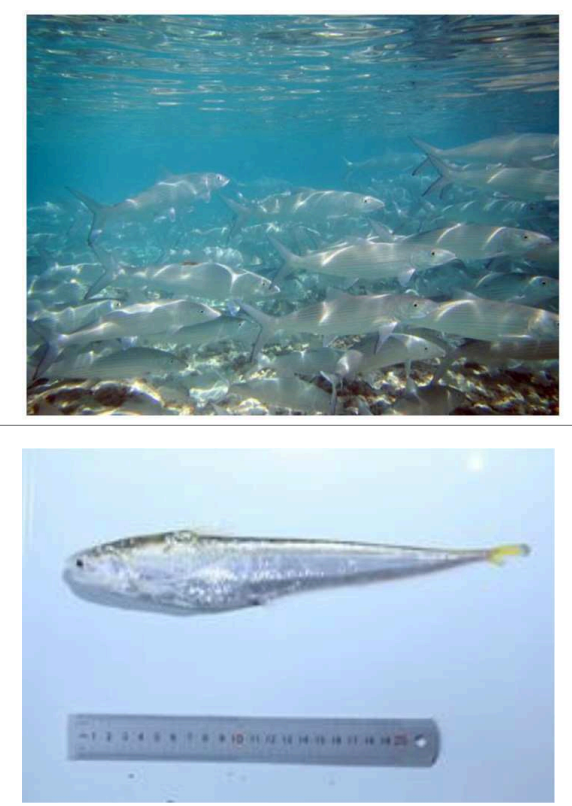

For many Neotropical fish species, adults migrate upstream to spawn during the wet season and the eggs and larvae are conveyed downstream to floodplains. Spent adults undergo a return migration downstream to suitable habitats for feeding (Pompeu et al., 2012). Biotelemetry data of Prochilodus costatus in the upper São Francisco River, Brazil revealed external drivers of the migration, specifically a preference for initiating migration at the beginning of the rainy season, when river discharge is low, on days with increased water level, and at times of new or waxing moon (de Magalhães Lopes et al., 2018). After spawning, most fish returned to the same location where they were captured/released, and for those tracked for two consecutive years, both upstream and downstream migration timings occurred only a few days apart (de Magalhães Lopes et al., 2019). Such homing behavior and temporal fidelity still needs to be confirmed for most other Neotropical migratory species. However, these findings pose additional challenges to the use of (predominantly upstream-directed) fishways as a management tool in the South American context, which is already controversial (Pompeu et al., 2012; Pelicice et al., 2015; photo: Pompeu).
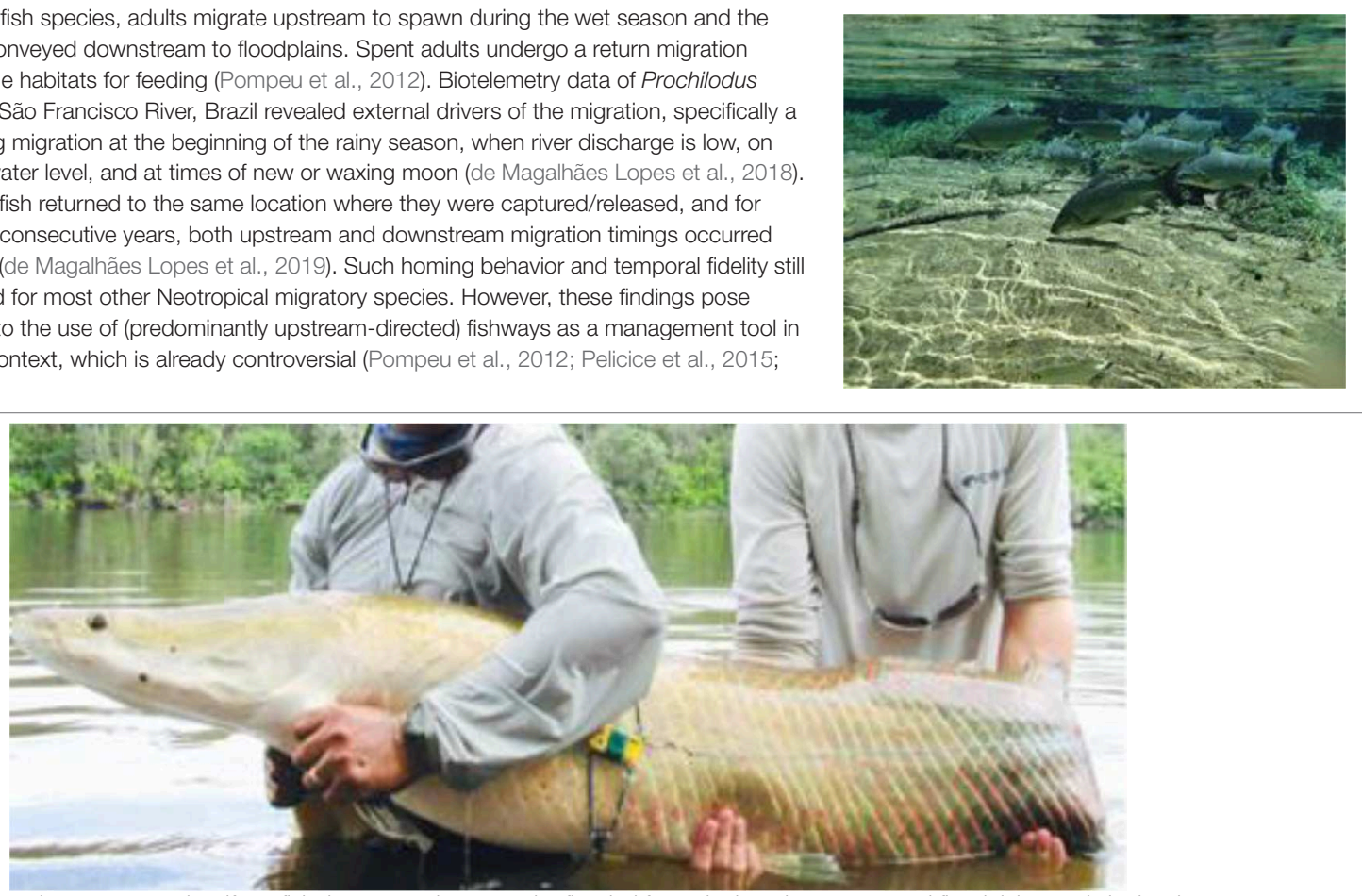

Arapaima arapaima is a migratory osteoglossiform fish that moves between the flooded forest in the rainy season and floodplain ponds in the dry season in several neotropical rivers, including Guyana's Essequibo watershed. The extent of its movements, migratory tendencies, and site fidelity are unknown, challenging efforts to establish protected areas, for example. The fish is threatened by overexploitation and although listed as 'unassessed' by IUCN it is a protected species in Guyana (Watson et al., 2016). Illegal fishing has historically been challenging to manage and legal fishing tourism has the potential to offer some relief if arapaima are resilient to catch-and-release fishing pressure (Lennox et al., 2018b). Given uncertainty about internal states and external drivers of migration, and that climate change could affect the length and intensity of the dry season, the future of arapaima will depend upon an adequate understanding of its movements to enable effective management (photo: Lennox). Mahseer (Tor spp.) such as the Critically Endangered cauvery 
humpbacked mahseer Tor remadevii (pictured), are iconic fishes exhibiting potamodromous migrations, most often to facilitate successful spawning (Nautiyal et al., 2001; Pinder et al., 2019). Mahseer are distributed in the monsoonal rivers of South and Southeast Asia, many of them heavily modified and fragmented due to hydropower dams. There is an urgent need to understand and resolve the impacts of river engineering projects on mahseer migrations. Particularly important are the Mekong and Ganges-Brahmaputra river systems which harbor many of the conservation-concern and data-deficient mahseer species. Preliminary understanding of Tor putitora revealed large-scale migrations ( $>50 \mathrm{~km}$ in a $48 \mathrm{~h}$ period) to warmer (non-snow fed) tributaries for spawning and homing behavior of individual fish to distinct tributaries on an annual basis (Fisheries Conservation Foundation and World

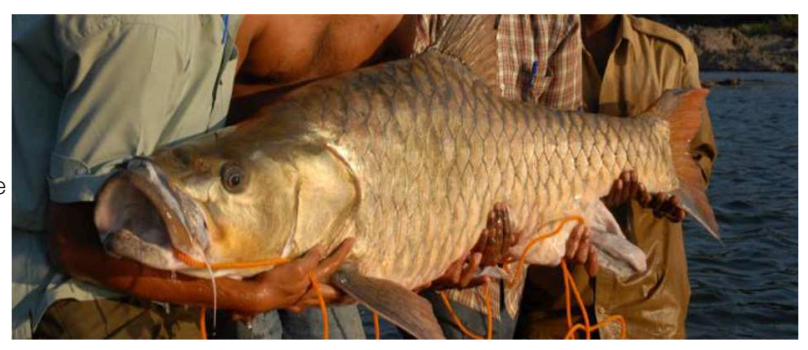
Wildlife Fund-Bhutan Unpublished; photo: John Bailey).

The Murray-Darling Basin in Australia is home to 56 fish species, all of which migrate at some stage of their life (Koehn and Lintermans, 2012). Golden perch are known to traverse thousands of kilometers when they migrate upstream in high densities (Reynolds, 1983). Movement of fish within and between river systems remains significantly restricted by over 10,000 dams and weirs without adequate fish passage (Baumgartner et al., 2009). Further, many fish, as well as sensitive eggs and larvae, are either diverted into water distribution canals, or pumped onto irrigation crops and die (Gilligan and Schiller, 2003). Significant numbers of fish also die when they pass through sluice type weirs (Baumgartner et al., 2006). These observations demonstrate that physiological traits may be important to understand migratory species. Passage requirements for adults are significantly different to those for early life history stages but all should be considered in a holistic sense when considering fish migration behavior (photo: Baumgartner).

Understanding the factors influencing fish migration can also be essential for management of invasive species. The sea lamprey (Petromyzon marinus) is a prolific invader in the North American Great Lakes that imparts substantial economic damage on fisheries (Smith and Tibbles, 1980; Christie and Goddard, 2003). Parasitic lamprey hatch in Great Lakes tributaries and the larvae metamorphose and sub-adults move to the lakes where they parasitize many different fish species including native lake trout (Salvelinus fontinalis, pictured). Lamprey control has benefited from installing unpassable barriers that block lamprey return migrations to spawning habitat, but the same barriers have impacted migrations of the diverse fish fauna other than leaping salmonids (McLaughlin et al., 2006). Understanding that lamprey use conspecific pheromones to navigate has allowed development of semiochemicals to distract them during migration (Siefkes, 2017; photo: Wikimedia Commons).

Eight species of yellowfish in southern Africa have been referred to as potamodromous (O'Brien et al., 2014). Conflicting literature regarding the migration behavior and distances traveled of the largemouth yellowfish (Labeobarbus kimberleyensis) suggests that studies may need to focus on detailing their behavior and the internal and external drivers of their migrations. The yellowfish are just one example of the many fish species in southern Africa that are sensitive to the increasing impacts of development, most notably from instream barriers ( $\bigcirc$ 'Brien et al., 2013). Without the necessary information on the migratory behavior of these freshwater fishes, water managers are not able to implement the necessary measures required to mitigate issues arising from development. It is thus critical that studies relating to the migratory strategies of fish in southern Africa, and indeed the entire continent, need to be prioritized (image: Brink).

The Mekong River is especially significant because migratory species, many of which provide substantial food security and economic benefits, are expected to decline in the next 20 years (Dugan et al., 2010). It has been long suspected that several large upstream migrant species in the Mekong might originate from the ocean (Ferguson et al., 2011). If this is true, then mainstem dam development on the Mekong may effectively extirpate entire endemic species by blocking access to critical habitat (Hogan et al., 2004). The Krempfii catfish (Pangasias krempfii) is so far the only described anadromous species in the Mekong (Hogan et al., 2007). It commences its spawning migration in February each year and spends up to 4 months reaching its spawning grounds above the Khone Falls, Laos. Upon hatching, the juveniles then commence a seaward migration. The migrations are cyclic, annual, and important for the long term sustainability of this species, which can grow to $1.4 \mathrm{~m}$ long and fetch up to $\$ 8$ USD per kilo on the local markets. The main threats to these species are hydropower dams, especially on the mainstem in Cambodia and Vietnam that may block access to the upstream spawning grounds (photo: Baumgartner).
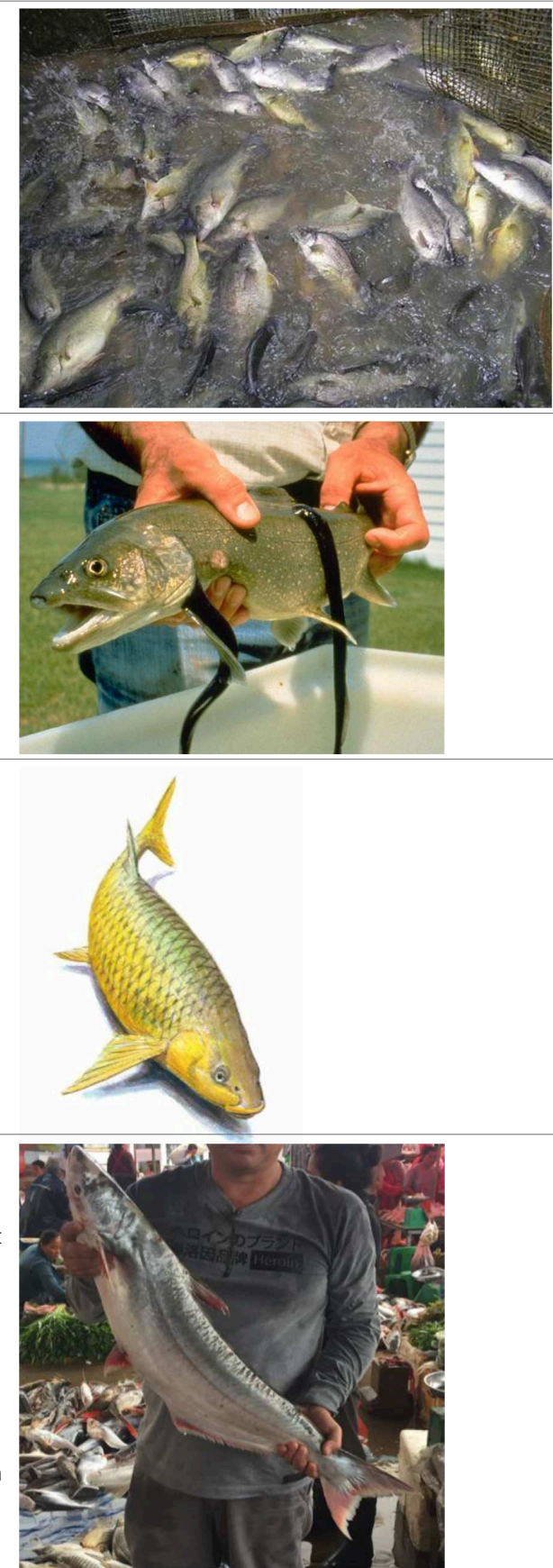
can shape an understanding of the hierarchical structure of fish populations, from within rivers and watersheds to regional and landscape scales, and designations of evolutionarily significant units (Dionne et al., 2008). Establishing the role of genetics in the migration of fish can then assist in informing how climatic and anthropogenic selective pressures may influence the genetics of fish populations, with implications for how activities structuring fish populations are managed (Quinn et al., 2007; Kovach et al., 2012).

Ecosystems are not isolated but interconnected by species that cross boundaries and transport matter and energy. Many terrestrial and aquatic food webs rely on migratory fishes directly or indirectly and we still have rudimentary understanding of many of these functional roles but are informed by a few well-studied species that are not necessarily representative of the diversity of migratory species. Salmonid migrations, specifically, have been extensively studied in the context of nutrient subsidies that adults bring from the marine environment into freshwater (Naiman et al., 2002). Recently, it was shown that salmon populations in freshwater correlate with geographically overlapping forest bird abundance and diversity, suggesting crucial linkages among species and habitats that merit further investigation (Wagner and Reynolds, 2019). Similar studies are needed on other migratory species that connect distant habitats, particularly in terms of forming metapopulations of their own species or their parasites and pathogens. How this operates vertically for fish that migrate between the shallows and depths or in many tropical and subtropical aquatic systems is particularly uncertain. The challenge, noted independently by many of the authors in this exercise, is developing international cooperation and an understanding of how to integrate this information into policy that can adequately and fairly protect species that cross jurisdictions and political boundaries (Dallimer and Strange, 2015; Midway et al., 2016).

Distinguishing migration from other movements is a challenge. Partial migration theory (Chapman et al., 2012a,b; Secor, 2015a), which draws on studies of birds and fishes to explain a latent capacity for all taxa to exhibit phenotypic variation in their migration behaviors, may help encapsulate the many different forms that migration can take in fishes. Physiological research, such as the genetics of seawater tolerance, will also contribute to an evolutionary perspective on the origins of fish migration (Ishikawa et al., 2019). Recent discoveries of diverse modes of seasonal and lifetime migrations within populations fit well with the theory of partial migration, and aligns well with recent research agendas on population connectivity (Cowen and Sponaugle, 2008), biocomplexity (Ruzzante et al., 2006), and resilience (Hilborn et al., 2003; Kerr et al., 2010). Partial migration may be fixed at the individual level (obligate partial migration) or conditiondependent (facultative partial migration; Boyle, 2008). The latter is especially pertinent to many fishes and to management of aquatic environments because long-lived individuals may migrate under some conditions (or in some years) but the same individuals may exhibit non-migratory behavior under other circumstances (or in other years), emphasizing their flexible and presumably adaptive responses to varying environmental conditions (Lucas and Baras, 2001). This also may inform the potential for irruptive behavior in some species. Developments in explanatory frameworks such as movement ecology and partial migration will be informed by increased attention to central mechanisms (e.g., locomotion, navigation, internal, and external drivers) and common emergent properties (schooling, population structure, range shifts, speciation) across taxa. Exploring how migration and dispersal interact along a continuum will assist in categorizing species and a better understanding fish migration in the future.

Much migration research focuses on active movement of animals but currents may transport eggs, larvae, and juveniles such that passive transport can form an integral component of many fish life cycles (e.g., Zeng et al., 2019). Although passive transport, particularly of fish larvae, has been a long-term focus of research and modeling in coastal and ocean systems (Harden Jones, 1968; Sinclair, 1988; Secor, 2015a), it has not received as much attention in freshwater ecosystems. Pelagic transport of eggs and larvae is common in many tropical freshwater fish taxa (Lucas and Baras, 2001) and those of goliath catfish (Brachyplatystoma) drift hundreds to thousands of kilometers toward estuarine reaches of South America's largest rivers (Barthem et al., 2017). In the ocean, adult plaice (Pleuronectes platessa) use selective tidal stream transport by moving vertically into the water column to select the direction of movement, potentially saving energy or assisting their conveyance to suitable habitat (Metcalfe et al., 1990). Hydraulics in both the marine and freshwater environments therefore have significant relevance to fish migration. There is strong potential for synergistic research between fish migration biology, river hydrogeomorphology and physical oceanography to study the role of currents on the fate and behavior of migratory species, with generation of predictions for climate change impacts.

Collaboration with Indigenous nations and local stakeholders/interests can help steer the research agenda to prioritize questions that we have set out here. Many projects have shown that strong collaborations yield active knowledge exchange. For example, in the Penobscot River, USA, access to thousands of kilometers of river were restored following dam removals primarily as a result of the active communication and involvement of all stakeholders from the beginning of the project (Opperman et al., 2011). However, a lot still needs to be learned about interdisciplinary research and community involvement in research and conservation efforts (Nguyen et al., 2016). This specifically includes improving communication among researchers, engineers, water managers, and authorities; reaching out to politicians; improving collaborations and commitment; and creating awareness and inspiring citizens (Young et al., 2016). The current focus on flyways for avian conservation has provided an instrument for international cooperation (Runge et al., 2015) and parallel efforts should be developed by identifying and protecting key spatiotemporal swimways for migratory fish (e.g., Pracheil et al., 2012). Global initiatives such as World Fish Migration Day (https://www. worldfishmigrationday.com/), International Year of the Salmon (https://yearofthesalmon.org/), and the emerging Swimway Global initiative (https://www.worldfishmigrationfoundation. 
com/projects/4/swimway-project) aim to improve public knowledge and unify organizations at a global level. Policy instruments and international cooperation are critical to realizing protection of migrants and the services and values they support.

We have generalized many of our questions to apply to the broad spatial, temporal, and geographic scales, but many of the initial formulations of the questions noted very specific threats to particular fish migrations that required investigation. Indeed, humans continue to look to the aquatic systems as resources to be tapped for solutions to global problems such as energy production, commerce, sewage treatment, stormwater impoundment, food and water security, recreation, and more (Fang and Jawitz, 2019; Reid et al., 2019). The myriad stressors emerging from the associated infrastructure affects fish habitat with noise, light pollution, electromagnetic interference, temperature and flow alteration, chemical pollution, water abstraction, and other threats, all of which have the potential to interfere with internal state, navigation, and locomotion. These and other threats are being explored but require additional attention and replication with different species, because many uncertainties remain and different species frequently respond very differently to common threats (e.g., Gill et al., 2012; Hellström et al., 2016; Filous et al., 2017). Introduction and spread of non-native species facilitated by humans and climate change have unknown consequences on migratory fish and their ecosystems. Novel predators and parasites are being introduced that can negatively affect migration (Boulêtreau et al., 2018).

A final challenge emerging from this exercise is the importance of prioritization. We have identified many questions with myriad implications for understanding, managing, and conserving ecosystem integrity in a changing world, and it is a great ambition to answer them all. Much of the research now conducted on fish is motivated to address threats from climate change or human activities but the efforts could significantly benefit from abetter fundamental understanding of migration and migratory species. Research necessarily tends to focus on species of economic importance or species at risk, but we must not lose sight of the importance of all species (e.g., Cooke et al., 2006). Studying migratory fishes in ecosystem contexts (i.e., with predators, prey, competitors, and pathogens) will be essential to understand how ecosystem processes operate and how migration functions to modulate the biotic and abiotic

\section{REFERENCES}

Abell, R., Allan, J. D., and Lehner, B. (2007). Unlocking the potential of protected areas for freshwaters. Biol. Conserv. 134, 48-63. doi: 10.1016/j.biocon.2006.08.017

Adams, A. J., and Cooke, S. J. (2015). Advancing the science and management of flats fisheries for bonefish, tarpon, and permit. Environ. Biol. Fish. 98, 2123-2131. doi: 10.1007/s10641-015-0446-9

Alexander, L. V., Zhang, X., Peterson, T. C., Caesar, J., Gleason, B., Klein Tank, A. M. G., et al. (2006). Global observed changes in daily climate extremes of temperature and precipitation. J. Geophys. Res. Atmos. 111:D05109. doi: 10.1029/2005JD006290 interactions that migratory species have in their environment. This directs attention to integrative and flexible models, which can make use of best available empirical studies and evaluate likely responses to future scenarios of change in probabilistic frameworks (e.g., Heath et al., 2008; Kerr et al., 2010; McGilliard et al., 2011). Ultimately, it is our hope that this list of questions is used to shape future projects, highlight the importance of migratory fishes, and to inform conservation decisions.

\section{AUTHOR CONTRIBUTIONS}

SC, CP, and RL conceived and outlined the study aims and objectives. All authors contributed questions, had input on organization into themes, and contributed to the direction and framing of the manuscript and writing. $\mathrm{LB}, \mathrm{KBr}, \mathrm{YC}$, AF, RL, PP, and RR compiled Box 1. AH conceptualized and illustrated Figure 1.

\section{FUNDING}

MA-M and SC were funded by the Natural Sciences and Engineering Research Council of Canada (NSERC), and the Canada Research Chairs program. EM was funded by NSERC. Several authors were part of HYCANOR, GLATOS, and the Ocean Tracking Network. JD is funded by the Research Council of Norway. AH was supported by Research Initiation Award \#16000691 from the US National Science Foundation. YC was funded by the Chinese Academy of Sciences (grants Y45Z04, Y62302, ZDRW-ZS-2017-3-2, Y55Z061201, and QYZDB-SSWSMC041) and WWF (grants 10002550 and 10003581). The Missouri Cooperative Fish and Wildlife Research Unit was sponsored jointly by the U.S. Geological Survey, Missouri Department of Conservation, University of Missouri, the Wildlife Management Institute, and the U.S. Fish and Wildlife Service. John Bailey provided the image of Tor remadevii.

\section{ACKNOWLEDGMENTS}

SJ-H acknowledges funding from the Welsh European Funding Office and European Regional Development Fund under project number 80761-SU-140 (West). Select imagery for Figure 1 was obtained courtesy of the Integration and Application Network, University of Maryland Center for Environmental Science (ian.umces.edu/imagelibrary/). disease risk. Science 331, 296-302. doi: 10.1126/science.1194694

Baker, R. R. (1978). The Evolutionary Ecology of Animal Migration. New York, NY: Holmes and Meier.

Barthem, R. B., Goulding, M., Leite, R. G., Canas, C., Forsberg, B., Venticinquem, E., et al. (2017). Goliath catfish spawning in the far western Amazon confirmed by the distribution of mature adults, drifting larvae and migrating adults. Sci. Rep. 7:41784. doi: 10.1038/ srep 41784

Baumgartner, L. J., Reynoldson, N., Cameron, L. M., and Stanger, J. G. (2009). Effects of irrigation pumps on riverine fish. Fish. Manag. Ecol. 16, 429-437. doi: 10.1111/j.1365-2400.2009.00693.x 
Baumgartner, L. J., Reynoldson, N., and Gilligan, D. M. (2006). Mortality of larval Murray cod (Maccullochella peelii peelii) and golden perch (Macquaria ambigua) associated with passage through two types of low-head weirs. Mar. Freshw. Res. 57, 187-191. doi: 10.1071/MF05098

Benstead, J. P., March, J. G., Pringle, C. M., and Scatena, F. N. (1999). Effects of a low-head dam and water abstraction on migratory tropical stream biota. Ecol. Appl. 9, 656-668. doi: 10.1890/1051-0761(1999)009[0656:EOALHD]2.0.CO;2

Birnie-Gauvin, K., Flávio, H., Kristensen, M. L., Walton-Rabideau, S., Cooke, S. J., Willmore, W. G., et al. (2019a). Cortisol predicts migration timing and success in both Atlantic salmon and sea trout kelts. Sci. Rep. 9:2422. doi: 10.1038/s41598-019-39153-x

Birnie-Gauvin, K., Franklin, P., Wilkes, M., and Aarestrup, K. (2018). Moving beyond fitting fish into equations: progressing the fish passage debate in the Anthropocene. Aquat. Conserv. Mar. Freshw. Ecosyst. 29, 1095-1105.

Birnie-Gauvin, K., Franklin, P., Wilkes, M., and Aarestrup, K. (2019b). Moving beyond fitting fish into equations: progressing the fish passage debate in the Anthropocene. Aquat. Conserv. 29, 1095-1105. doi: 10.1002/aqc.2946

Bordeleau, X., Davidsen, J. G., Eldøy, S. H., Sjursen, A. D., Whoriskey, F. G., and Crossin, G. T. (2018). Nutritional correlates of spatiotemporal variations in the marine habitat use of brown trout (Salmo trutta) veteran migrants. Can. J. Fish. Aquat. Sci. 75, 1744-1754. doi: 10.1139/cjfas-2017-0350

Both, C., and Visser, M. E. (2001). Adjustment to climate change is constrained by arrival date in a long-distance migrant bird. Nature 411:296. doi: 10.1038/35077063

Boulêtreau, S., Gaillagot, A., Carry, L., Tétard, S., De Oliveira, E., and Santoul, F. (2018). Adult Atlantic salmon have a new freshwater predator. PLoS ONE 13:e0196046. doi: 10.1371/journal.pone.0196046

Bowlin, M. S., Bisson, I.-A., Shamoun-Baranes, J., Reichard, J. D., Sapir, N., Marra, P. P., et al. (2010). Grand challenges in migration biology. Integr. Comp. Biol. 50, 261-279. doi: $10.1093 /$ icb/icq013

Boyle, A. (2008). Partial migration in birds: testing three hypotheses in a tropical lekking frugivore. J. Anim. Ecol. 77, 1122-1128. doi: $10.1111 / \mathrm{j} .1365-2656.2008 .01451 . x$

Bracken, F. S., Hoelzel, A. R., Hume, J. B., and Lucas, M. C. (2015). Contrasting population genetic structure among freshwater-resident and anadromous lampreys: the role of demographic history, differential dispersal and anthropogenic barriers to movement. Mol. Ecol. 24, 1188-1204. doi: $10.1111 / \mathrm{mec} .13112$

Bradshaw, W. E., and Holzapfel, C. M. (2007). Evolution of animal photoperiodism. Аnnu. Rev. Ecol. Evol. Syst. 38, 1-25. doi: 10.1146/annurev.ecolsys.37.091305.110115

Brink, K., Gough, P., Royte, J., Schollema, P. P., and Wanningen, H. (2018). From Sea to Source 2.0. Protection and Restoration of Fish Migration in Rivers Worldwide. World Fish Migration Foundation, Netherlands.

Brown, C., and Laland, K. N. (2003). Social learning in fishes: a review. Fish Fish. 4, 280-288. doi: 10.1046/j.1467-2979.2003.00122.x

Brownscombe, J. W., Cooke, S. J., Algera, D. A., Hanson, K. C., Eliason, E. J., Burnett, N. J., et al. (2017). Ecology of exercise in wild fish: integrating concepts of individual physiological capacity, behavior, and fitness through diverse case studies. Integr. Comp. Biol. 57, 281-292. doi: 10.1093/icb/ icx012

Chapman, B. B., Hulthén, K., Brodersen, J., Nilsson, P. A., Skov, C., Hansson, L.-A., and Brönmark, C. (2012b). Partial migration in fishes: causes and consequences. J. Fish Biol. 81, 456-478. doi: 10.1111/j.1095-8649.2012. 03342.x

Chapman, B. B., Skov, C., Hulthén, K., Brodersen, J., Nilsson, P. A., Hansson, L. A., et al. (2012a). Partial migration in fishes: definitions, methodologies and taxonomic distribution. J. Fish Biol. 81, 479-499. doi: $10.1111 / j .1095-8649.2012 .03349 . x$

Chessman, B. C. (2013). Identifying species at risk from climate change: traits predict the drought vulnerability of freshwater fishes. Biol. Conserv. 160, 40-49. doi: 10.1016/j.biocon.2012.12.032

Chhatre, A., and Saberwal, V. (2005). Political incentives for biodiversity conservation. Conserv. Biol. 19, 310-317. doi: $10.1111 / j .1523-1739.2005 .00012 . x$

Childress, E. S., and McIntyre, P. B. (2015). Multiple nutrient subsidy pathways from a spawning migration of iteroparous fish. Freshw. Biol. 60, 490-499. doi: $10.1111 /$ fwb. 12494
Christie, G. C., and Goddard, C. I. (2003). Sea Lamprey International Symposium (SLIS II): advances in the integrated management of sea lamprey in the Great Lakes. J. Great Laes Res. 29, 1-14. doi: 10.1016/S0380-1330(03) 70474-2

Cooke, S. J., Bunt, C. M., Hamilton, S. J., Jennings, C. A., Pearson, M. P., Cooperman, M. S., et al. (2006). Threats, conservation strategies, and prognosis for suckers (Catostomidae) in North America: insights from regional case studies of a diverse family of non-game fishes. Biol. Conserv. 121, 317-331. doi: 10.1016/j.biocon.2004.05.015

Cooke, S. J., Paukert, C., and Hogan, Z. (2012). Endangered river fish: factors hindering conservation and restoration. Endanger. Spec. Res. 17, 179-191. doi: $10.3354 /$ esro0426

Cowen, R. K., and Sponaugle, S. (2008). Larval dispersal and marine population connectivity. Ann. Rev. Mar. Sci. 1, 443-466. doi: 10.1146/annurev.marine.010908.163757

Dallimer, M., and Strange, N. (2015). Why socio-political borders and boundaries matter in conservation. Trends Ecol. Evol. 30, 132-139. doi: 10.1016/j.tree.2014.12.004

de Magalhães Lopes, J., Alves, C. B. M., Peressin, A., and Pompeu, P. S. (2018). Influence of rainfall, hydrological fluctuations, and lunar phase on spawning migration timing of the Neotropical fish Prochilodus costatus. Hydrobiologia 818, 145-161. doi: 10.1007/s10750-018-3601-4

de Magalhães Lopes, J., Pompeu, P. S., Alves, C. B. M., Peressin, A., Prado, I. G., Suzuki, F. M., et al. (2019). The critical importance of an undammed river segment to the reproductive cycle of a migratory Neotropical fish. Ecol. Freshw. Fish. 28. 302-316. doi: 10.1111/eff.12454

Dingle, H., and Drake, V. A. (2007). What is migration? Bioscience 57, 113-121. doi: $10.1641 /$ B570206

Dionne, M., Caron, F., Dodson, J. J., and Bernatchez, L. (2008). Landscape genetics and hierarchical genetic structure in Atlantic salmon: the interaction of gene flow and local adaptation. Mol. Ecol. 17, 2382-2396. doi: 10.1111/j.1365-294X.2008.03771.x

Dodson, J. J. (1988). The nature and role of learning in the orientation and migratory behavior of fishes. Environ. Biol. Fish. 23, 161-182.

Dou, S. Z., Yokouchi, K., Yu, X., Cao, L., Kuroki, M., Otake, T., et al. (2012). The migratory history of anadromous and non-anadromous tapertail anchovy Coilia nasus in the Yangtze River Estuary revealed by the otolith Sr: Ca ratio. Environ. Biol. Fish. 95, 481-490. doi: 10.1007/s10641-012-0042-1

Dugan, P. J., Barlow, C., Agostinho, A. A., Baran, E., Cada, G. F., Chen, D., et al. (2010). Fish migration, dams, and loss of ecosystem services in the Mekong Basin. Ambio 39, 344-348. doi: 10.1007/s13280-010-0036-1

Durif, C. M., Browman, H. I., Phillips, J. B., Skiftesvik, A. B., Vøllestad, L. A., and Stockhausen, H. H. (2013). Magnetic compass orientation in the European eel. PLoS ONE 8:e59212. doi: 10.1371/journal.pone.0059212

Eliason, E. J., Clark, T. D., Hague, M. J., Hanson, L. M., Gallagher, Z. S., Jeffries, K. M., et al. (2011). Differences in thermal tolerance among sockeye salmon populations. Science 332, 109-112. doi: 10.1126/science.1199158

Fang, Y., and Jawitz, J. W. (2019). The evolution of human population distance to water in the USA from 1790 to 2010. Nat. Comm. 10:430. doi: 10.1038/s41467-019-08366-z

Ferguson, J. W., Healey, M., Dugan, P., and Barlow, C. (2011). Potential effects of dams on migratory fish in the Mekong river: lessons from salmon in the Fraser and Columbia rivers. Environ. Manag. 47, 141-159. doi: 10.1007/s00267-010-9563-6

Filous, A., Friedlander, A. M., Koike, H., Lammers, M., Wong, A., Stone, K., et al. (2017). Displacement effects of heavy human use on coral reef predators within the Molokini Marine Life Conservation District. Mar. Poll. Bull. 121, 274-281. doi: 10.1016/j.marpolbul.2017.06.032

Free, C. M., Thorson, J. T., Pinsky, M. L., Oken, K. L., Wiedenmann, J., and Jensen, O. P. (2019). Impacts of historical warming on marine fisheries production. Science 363, 979-983. doi: 10.1126/science.aau1758

Fuller, M. R., Doyle, M. W., and Strayer, D. L. (2015). Causes and consequences of habitat fragmentation in river networks. Ann. N.Y. Acad. Sci. 1355, 31-51. doi: $10.1111 /$ nyas. 12853

Gill, A. B., Bartlett, M., and Thomsen, F. (2012). Potential interactions between diadromous fishes of UK conservation importance and the electromagnetic fields and subsea noise from marine renewable energy developments. J. Fish Biol. 81, 664-695. doi: 10.1111/j.1095-8649.2012.03374.x 
Gilligan, D. M., and Schiller, C. B. (2003). Downstream Transport of Larval and Juvenile Fish in the Murray River. NSW Fisheries Final Report Series 50, NSW Fisheries, Cronulla.

Gunningham, N., Grabosky, P., and Sinclair, D. (1998). Smart regulation: Designing Environmental Policy. Oxford: Oxford University Press.

Hall, C. J., Jordaan, A., and Frisk, M. G. (2012). Centuries of anadromous forage fish loss: consequences for ecosystem connectivity and productivity. Bioscience 62, 723-731. doi: 10.1525/bio.2012.62.8.5

Halpern, B. S., Walbridge, S., Selkoe, K. A., Kappel, C. V., Micheli, F., D’Agrosa, C., et al. (2008). A global map of human impact on marine ecosystems. Science 319, 948-952. doi: 10.1126/science.1149345

Harden Jones, F. R. (1968). Fish Migration. London: Edward Arnold.

Hauer, C., Leitner, P., Unfer, G., Pulg, U., Habersack, H., and Graf, W. (2018). "The role of sediment and sediment dynamics in the aquatic environment," in Riverine Ecosystem Management, eds S. Schmutz and J. Sendzimir (Cham: Springer), 151-169. doi: 10.1007/978-3-319-73250-3_8

Heath, M. R., Kunzlik, P. A., Gallego, A., Holmes, S. J., and Wright, P. J. (2008). A model of meta-population dynamics for North Sea and West of Scotland cod-The dynamic consequences of natal fidelity. Fish. Res. 93, 92-116. doi: 10.1016/j.fishres.2008.02.014

Hecht, B. C., Hard, J. J., Thrower, F. P., and Nichols, K. M. (2015). Quantitative genetics of migration-related traits in rainbow and steelhead trout. G3 5, 873-889. doi: $10.1534 / \mathrm{g} 3.114 .016469$

Hellström, G., Klaminder, J., Finn, F., Persson, L., Alanärä, A., Jonsson, M., et al. (2016). GABAergic anxiolytic drug in water increases migration behaviour in salmon. Nat. Commun. 7:13460. doi: 10.1038/ncomms13460

Hendry, A. P., Wenburg, J. K., Bentzen, P., Volk, E. C., and Quinn, T. P. (2000). Rapid evolution of reproductive isolation in the wild: evidence from introduced salmon. Science 290, 516-518. doi: 10.1126/science.290.5491.516

Hidalgo, M., Secor, D. H., and Browman, H. I. (2016). Observing and managing seascapes: linking synoptic oceanography, ecological processes, and geospatial modeling. ICES J. Mar. Sci. 73, 1825-1830. doi: 10.1093/icesjms/fsw079

Hilborn, R., Quinn, T. P., Schindler, D. E., and Rogers, D. E. (2003). Biocomplexity and fisheries sustainability. Proc. Nat. Acad. Sci. U.S.A. 100, 6564-6568. doi: 10.1073/pnas. 1037274100

Hinch, S. G., and Bratty, J. (2000). Effects of swim speed and activity pattern on success of adult sockeye salmon migration through an area of difficult passage. Trans. Am. Fish. Soc. 129, 598-606. doi: 10.1577/15488659(2000)129<0598:EOSSAA >2.0.CO;2

Hoegh-Guldberg, O., and Bruno, J. F. (2010). The impact of climate change on the world's marine ecosystems. Science 328, 1523-1528. doi: $10.1126 /$ science. 1189930

Hogan, Z., Baird, I. G., Radtke, R., and Zande, M. J. V. (2007). Long distance migration and marine habitation in the tropical Asian catfish, Pangasius krempfi. J. Fish Biol. 71, 818-832. doi: 10.1111/j.1095-8649.2007. 01549.x

Hogan, Z., Moyle, P., May, B., Vander-Zanden, J., and Baird, I. G. (2004). The imperiled giants of the Mekong. Am. Sci. 92, 228-237. doi: 10.1511/2004. 47.929

Hohensinner, S., Hauer, C., and Muhar, S. (2018). "River morphology, channelization, and habitat restoration," in Riverine Ecosystem Management, eds S. Schmutz and J. Sendzimir (Cham: Springer), 41-65.

Horodysky, A. Z., Cooke, S. J., and Brill, R. W. (2015). Physiology in the service of fisheries science: why thinking mechanistically matters. Rev. Fish Biol. Fish. 25, 425-447. doi: 10.1007/s11160-015-9393-y

Hyndes, G. A., Nagelkerken, I., McLeod, R. J., Connolly, R. M., Lavery, P. S., and Vanderklift, M. A. (2014). Mechanisms and ecological role of carbon transfer within coastal seascapes. Biol. Rev. 89, 232-254. doi: 10.1111/brv.12055

Ishikawa, A., Kabeya, N., Ikeya, K., Kakioka, R., Cech, J. N., Osada, N., et al. (2019). A key metabolic gene for recurrent freshwater colonization and radiation in fishes. Science 364, 886-889. doi: 10.1126/science.aau5656

Januchowski-Hartley, S. R., McIntyre, P. B., Diebel, M., Doran, P. J., Infante, D. M., Joseph, C., et al. (2013). Restoring aquatic ecosystem connectivity requires expanding inventories of both dams and road crossings. Front. Ecol. Environ. 11, 211-217. doi: 10.1890/120168

Jørgensen, C., Dunlop, E. S., Opdal, A. F., and Fiksen, Ø. (2008). The evolution of spawning migrations: state dependence and fishing-induced changes. Ecology 89, 3436-3448. doi: 10.1890/07-1469.1
Jørgensen, C., Enberg, K., Dunlop, E. S., Arlinghaus, R., Boukal, D. S., Brander, K., et al. (2007). Managing evolving fish stocks. Science 318, 1247-1248. doi: $10.1126 /$ science. 1148089

Kerr, L. A., Cadrin, S. X., and Secor, D. H. (2010). The role of spatial dynamics in the stability, resilience, and productivity of fish populations: an evaluation based on white perch in the Chesapeake Bay. Ecol. Appl. 20, 497-507. doi: 10.1890/08-1382.1

Kess, T., Bentzen, P., Lehnert, S. J., Sylvester, E. V. A., Lien, S., Kent, M. P., et al. (2019). A migration-associated supergene reveals loss of biocomplexity in Atlantic cod. Sci. Adv. 5:eaav2461. doi: 10.1126/sciadv.aav2461

Klemetsen, A. (2010). The charr problem revisited: exceptional phenotypic plasticity promotes ecological speciation in postglacial lakes. Freshw. Rev. 3, 49-74. doi: 10.1608/FRJ-3.1.3

Koehn, J. D., and Lintermans, M. (2012). A strategy to rehabilitate fishes of the Murray-Darling Basin, south-eastern Australia. Endanger. Spec. Res. 16, 165-181. doi: 10.3354/esr00398

Kovach, R. P., Gharrett, A. J., and Tallmon, D. A. (2012). Genetic change for earlier migration timing in a pink salmon population. Proc. R. Soc. B Biol. Sci. 279, 3870-3878. doi: 10.1098/rspb.2012.1158

Kovach, R. P., Muhlfeld, C. C., Boyer, M. C., Lowe, W. H., Allendorf, F. W., and Luikart, G. (2015). Dispersal and selection mediate hybridization between a native and invasive species. Proc. R. Soc. B Biol. Sci. 282:20142454. doi: 10.1098/rspb.2014.2454

Lange, P., Driessen, P. P., Sauer, A., Bornemann, B., and Burger, P. (2013). Governing towards sustainability - conceptualizing modes of governance. J. Environ. Pol. Plann. 15, 403-425. doi: 10.1080/1523908X.2013.769414

Lascelles, B., Notarbartolo Di Sciara, G., Agardy, T., Cuttelod, A., Eckert, S., Glowka, L., et al. (2014). Migratory marine species: their status, threats and conservation management needs. Aquat. Conserv. 24, 111-127. doi: $10.1002 /$ aqc. 2512

Lehodey, P., Alheit, J., Barange, M., Baumgartner, T., Beaugrand, G., Drinkwater, K., et al. (2006). Climate variability, fish, and fisheries. J. Clim. 19, 5009-5030. doi: $10.1175 /$ JCLI3898.1

Lennox, R. J., Brownscombe, J. W., Cooke, S. J., and Danylchuk, A. J. (2018b). Postrelease behaviour and survival of recreationally-angled arapaima (Arapaima cf. arapaima) assessed with accelerometer biologgers. Fish. Res. 207, 197-203. doi: 10.1016/j.fishres.2018.05.007

Lennox, R. J., Engler-Palma, C., Kowarski, K., Filous, A., Whitlock, R., Cooke, S. J., et al. (2018a). Optimizing marine spatial plans with animal tracking data. Can. J. Fish. Aquat. Sci. 76, 497-509. doi: 10.1139/cjfas-2017-0495

Link, J. S., Bundy, A., Overholtz, W. J., Shackell, N., Manderson, J., Duplisea, D., et al. (2011). Ecosystem-based fisheries management in the Northwest Atlantic. Fish Fish. 12, 152-170. doi: 10.1111/j.1467-2979.2011.00411.x

Lohmann, K. J., Lohmann, C. M., and Endres, C. S. (2008). The sensory ecology of ocean navigation. J. Exp. Biol. 211, 1719-1728. doi: 10.1242/jeb.015792

Longcore, T., and Rich, C. (2004). Ecological light pollution. Front. Ecol. Environ. 2, 191-198. doi: 10.1890/1540-9295(2004)002[0191:ELP]2.0.CO;2

Lowerre-Barbieri, S. K., Kays, R., Thorson, J. T., and Wikelski, M. (2019). The ocean's movescape: fisheries management in the bio-logging decade (2018-2028). ICES J. Mar. Sci. 76, 477-488. doi: 10.1093/icesjms/fsy211

Lucas, M., and Baras, E. (2001). Migration of Freshwater Fishes. Oxford: Blackwell. doi: 10.1002/9780470999653

Lynch, A. J., Myers, B. J. E., Chu, C., Eby, L. A., Falke, J. A., Kovach, R. P., et al. (2016). Climate change effects on North American inland fish populations and assemblages. Fisheries 41, 346-361. doi: 10.1080/03632415.2016.1186016

McGilliard, C. R., Punt, A. E., and Hilborn, R. (2011). Spatial structure induced by marine reserves shapes population responses to catastrophes in mathematical models. Ecol. Appl. 21, 1399-1409. doi: 10.1890/10-0001.1

McLaughin, R. L., Smyth, E. R. B., Castro-Santos, T., Jones, M. L., Koops, M. A., Pratt, T. C., et al. (2013). Unintended consequences and trade-offs of fish passage. Fish Fish. 14, 580-604. doi: 10.1111/faf.12003

McLaughlin, R. L., Porto, L., Noakes, D. L. G., Baylis, J. R., Carl, L. M., Dodd, H. R., et al. (2006). Effects of low-head barriers on stream fishes: taxonomic affiliations and morphological correlates of sensitive species. Can. J. Fish. Aquat. Sci. 63, 766-779. doi: 10.1139/f05-256

Metcalfe, J. D., Arnold, G. P., and Webb, P. W. (1990). The energetics of migration by selective tidal stream transport: an analysis for plaice tracked in the southern North Sea. J. Mar. Biol. Soc. 70, 149-162. doi: 10.1017/S0025315400034275 
Midway, S. R., Wagner, T., Zydlewski, J. D., Irwin, B. J., and Paukert, C. P. (2016). Transboundary fisheries science: meeting the challenges of inland fisheries management in the 21st century. Fisheries 41, 537-546. doi: 10.1080/03632415.2016.1208090

Miller, K. M., Teffer, A., Tucker, S., Li, S., Schulze, A. D., Trudel, M., et al. (2014). Infectious disease, shifting climates, and opportunistic predators: cumulative factors potentially impacting wild salmon declines. Evol. Appl. 7, 812-855. doi: 10.1111/eva.12164

Mumby, P. J. (2006). Connectivity of reef fish between mangroves and coral reefs: algorithms for the design of marine reserves at seascape scales. Biol. Conserv. 128, 215-222. doi: 10.1016/j.biocon.2005.09.042

Murchie, K. J., Shultz, A. D., Stein, J. A., Cooke, S. J., Lewis, J., Franklin, J., et al. (2015). Defining adult bonefish (Albula vulpes) movement corridors around Grand Bahama in the Bahamian Archipelago. Environ. Biol. Fish. 98, 2203-2212. doi: 10.1007/s10641-015-0422-4

Myers, G. S. (1949). Usage of anadromous, catadromous and allied terms for migratory fishes. Copeia 1949, 89-97. doi: 10.2307/1438482

Naiman, R. J., Bilby, R. E., Schindler, D. E., and Helfield, J. M. (2002). Pacific salmon, nutrients, and the dynamics of freshwater and riparian ecosystems. Ecosystems 5, 399-417. doi: 10.1007/s10021-001-0083-3

Nathan, R., Getz, W. M., Revilla, E., Holyoak, M., Kadmon, R., Saltz, D., et al. (2008). A movement ecology paradigm for unifying organismal movement research. Proc. Nat. Acad. Sci U.S.A. 105, 19052-19059. doi: $10.1073 /$ pnas. 0800375105

Nautiyal, P., Bahuguna, S. N., and Thapliyal, R. P. (2001). The role of ecological factors in governing the direction, time and purpose of migration in Himalayan Mahseer Tor putitora (Ham.). Appl. Fish. Aquacult. 1, 133-138.

Nguyen, V. M., Young, N., Hinch, S. G., and Cooke, S. J. (2016). Getting past the blame game: convergence and divergence in perceived threats to salmon resources among anglers and indigenous fishers in Canada's lower Fraser River. Ambio 45, 591-601. doi: 10.1007/s13280-016-0769-6

Nieminen, E., Hyytiäinen, K., and Lindroos, M. (2017). Economic and policy considerations regarding hydropower and migratory fish. Fish Fish. 18, 54-78. doi: $10.1111 /$ faf.12167

O’Brien, G. C., Jacobs, F., Cronje, L., Wepener, V., and Smit, N. J. (2013). Habitat preferences and movement of adult yellowfishes in the Vaal River, South Africa. S. Afr. J. Sci. 109, 1-8. doi: 10.1590/sajs.2013/20120095

O'Brien, G. C., Jacobs, F. J., Botha, I. F., and O'Brien, M. (2014). Manual to Monitor Fish Behaviour and Water Variables Remotely in Real Time in South African Inland Aquatic Ecosystems, Pretoria: Water Research Commission. WRC Report no. K8/1042

Olsson, I. C., Greenberg, L. A., Bergman, E., and Wysujack, K. (2006). Environmentally induced migration: the importance of food. Ecol. Lett. 9, 645-651. doi: 10.1111/j.1461-0248.2006.00909.x

Opperman, J., Royte, J., Banks, J., Day, L., and Apse, C. (2011). The Penobscot River, Maine, USA: a basin scale approach to balancing power generation and ecosystems restoration. Ecol. Soc. 16:7. doi: 10.5751/ES-04117-160307

Orsborn, J. F. (1987). "Fishways-historical assessment of design practices," in Common Strategies of Anadromous and Catadromous Fishes, ed M. J. Dadswell, R. J. Klauda, C. M. Moffitt, R. L. Saunders, R. A. Rulifson, and J. E. Cooper (Bethesda, MD, American Fisheries Society Symposium), 122-130.

Ottersen, G., Kim, S., Huse, G., Polovina, J. J., and Stenseth, N. C. (2010). Major pathways by which climate may force marine fish populations. J. Mar. Sys. 79, 343-360. doi: 10.1016/j.jmarsys.2008.12.013

Palkovacs, E. P., Kinnison, M. T., Correa, C., Dalton, C. M., and Hendry, A. P. (2012). Fates beyond traits: ecological consequences of human-induced trait change. Evol. Appl. 5, 183-191. doi: 10.1111/j.1752-4571.2011.00212.x

Pelicice, F. M., Pompeu, P. S., and Agostinho, A. A. (2015). Large reservoirs as ecological barriers to downstream movements of Neotropical migratory fish. Fish Fish. 16, 697-715. doi: 10.1111/faf.12089

Perrier, C., Evanno, G., Belliard, J., Guyomard, R., and Bagliniere, J. L. (2009). Natural recolonization of the Seine River by Atlantic salmon (Salmo salar) of multiple origins. Can. J. Fish. Aquat. Sci. 67, 1-4. doi: 10.1139/F09-190

Pinder, A., Britton, J. R., Harrison, A., Nautiyal, P., Bower, S. D., Cooke, S. J., et al. (2019). Mahseer (Tor spp.) fishes of the world: status, challenges and opportunities for conservation. Fish Fish. 29, 417-452. doi: 10.1007/s11160-019-09566-y
Pompeu, P. S., Agostinho, A. A., and Pelicice, F. M. (2012). Existing and future challenges: the concept of successful fish passage in South America. Riv. Res. Appl. 28, 504-512. doi: 10.1002/rra.1557

Pracheil, B. M., Pegg, M. A., Powell, L. A., and Mestl, G. E. (2012). Swimways: protecting paddlefish through movement-centered management. Fisheries 37, 449-457. doi: $10.1080 / 03632415.2012 .722877$

Prince, D. J., O’Rourke, S. M., Thompson, T. Q., Ali, O. A., Lyman, H. S., Saglam, I. K., et al. (2017). The evolutionary basis of premature migration in Pacific salmon highlights the utility of genomics for informing conservation. Sci. Adv. 3:e1603198. doi: 10.1126/sciadv.1603198

Pulido, F. (2011). Evolutionary genetics of partial migration-the threshold model of migration revis (it) ed. Oikos 120, 1776-1783. doi: 10.1111/j.1600-0706.2011.19844.x

Putman, N. F., Scanlan, M. M., Billman, E. J., O’Neil, J. P., Couture, R. B., Quinn, T. P., et al. (2014). An inherited magnetic map guides ocean navigation in juvenile Pacific salmon. Curr. Biol. 24, 446-450. doi: 10.1016/j.cub.2014.01.017

Quinn, T. P., Hodgson, S., Flynn, L., Hilborn, R., and Rogers, D. E. (2007). Directional selection by fisheries and the timing of sockeye salmon (Oncorhynchus nerka) migrations. Ecol. Appl. 17, 731-739. doi: 10.1890/06-0771

Radinger, J., and Wolter, C. (2014). Patterns and predictors of fish dispersal in rivers. Fish Fish. 15, 456-473. doi: 10.1111/faf.12028

Rahel, F. J., and McLaughlin, R. L. (2018). Selective fragmentation and the management of fish movement across anthropogenic barriers. Ecol. Appl. 28, 2066-2081. doi: 10.1002/eap.1795

Reid, A. J., Carlson, A. K., Creed, I. F., Eliason, E. J., Gell, P. A., Johnson, P. T. J., et al. (2019). Emerging threats and persistent conservation challenges for freshwater biodiversity. Biol. Rev. 19, 849-873. doi: 10.1111/brv.12480

Reidy, S. P., Kerr, S. R., and Nelson, J. A. (2000). Aerobic and anaerobic swimming performance of individual Atlantic cod. J. Exp. Biol. 203, 347-357.

Reynolds, L. F. (1983). Migration patterns of five fish species in the Murray-Darling River system. Aus. J. Mar. Freshw. Res. 34, 857-871. doi: 10.1071/MF9830857

Riccioni, G., Landi, M., Ferrara, G., Milano, I., Cariani, A., Zane, L., et al. (2010). Spatio-temporal population structuring and genetic diversity retention in depleted Atlantic bluefin tuna of the Mediterranean Sea. Proc. Nat. Acad. Sci U.S.A. 107, 2102-2107. doi: 10.1073/pnas.0908281107

Robinson, R. A., Crick, H. Q., Learmonth, J. A., Maclean, I. M., Thomas, C. D., Bairlein, F., et al. (2009). Travelling through a warming world: climate change and migratory species. Endanger. Spec. Res. 7, 87-99. doi: 10.3354/esr00095

Roscoe, D. W., and Hinch, S. G. (2010). Effectiveness monitoring of fish passage facilities: historical trends, geographic patterns and future directions. Fish Fish. 11, 12-33. doi: 10.1111/j.1467-2979.2009.00333.x

Runge, C. A., Martin, T. G., Possingham, H. P., Willis, S. G., and Fuller, R. A. (2014). Conserving mobile species. Front. Ecol. Environ. 12, 395-402. doi: $10.1890 / 130237$

Runge, C. A., Watson, J. E., Butchart, S. H., Hanson, J. O., Possingham, H. P., and Fuller, R. A. (2015). Protected areas and global conservation of migratory birds. Science 350, 1255-1258. doi: 10.1126/science.aac9180

Ruzzante, D. E., Mariani, S., Bekkevold, D., André, C., Mosegaard, H., Clausen, L. A., et al. (2006). Biocomplexity in a highly migratory pelagic marine fish, Atlantic herring. Proc. R. Soc. B Biol. Sci. 273, 1459-1464. doi: $10.1098 / \mathrm{rspb} .2005 .3463$

Secor, D. H. (2015a). Migration Ecology of Marine Fishes. Baltimore, MA: JHU Press.

Secor, D. H. (2015b). American eel: when does diversity matter? Fisheries 40, 462-463. doi: 10.1080/03632415.2015.1073152

Sfakiotakis, M., Lane, D. M., and Davies, J. B. C. (1999). Review of fish swimming modes for aquatic locomotion. IEEE J. Oceanic Eng. 24, 237-252. doi: $10.1109 / 48.757275$

Shuter, J. L., Broderick, A. C., Agnew, D. J., Jonzen, N., Godley, B. J., MilnerGulland, E. J., et al. (2010). "Conservation and management of migratory species," in Animal Migration: A Synthesis, eds E. J. Milner-Gulland, J. Fryxell, and Sinclair, A. R. E (Oxford, Oxford University Press), 172-206. doi: 10.1093/acprof:oso/9780199568994.003.0011

Siefkes, M. J. (2017). Use of physiological knowledge to control the invasive sea lamprey (Petromyzon marinus) in the Laurentian Great Lakes. Conserv. Physiol. 5:cox031. doi: 10.1093/conphys/cox031 
Silva, A. T., Lucas, M. C., Castro-Santos, T., Katopodis, C., Baumgartner, L. J., Thiem, J. D., et al. (2018). The future of fish passage science, engineering, and practice. Fish Fish. 19, 340-362. doi: 10.1111/faf.12258

Sinclair, M. (1988). Marine Populations: An Essay on Population Regulation and Speciation. Seattle, WA: University Washington Press.

Smith, B. R., and Tibbles, J. J. (1980). Sea lamprey (Petromyzon marinus) in Lakes Huron, Michigan, and Superior: history of invasion and control, 1936-78. Can. J. Fish. Aquat. Sci. 37, 1780-1801. doi: 10.1139/f80-222

So, N., van Hout, J. K. J., and Volckaert, F. A. M. (2006). Genetic diversity and population history of the migratory catfishes Pangasianodon hypophthalmus and Pangasius bocourti in the Cambodian Mekong River. Fish. Sci. 72, 469-476. doi: 10.1111/j.1444-2906.2006.01174.x

Ueda, H. (2018). "Migration and navigation in fish," in Encyclopedia of Reproduction. 2nd Edn, Vol. 6, ed M. K. Skinner (Elsevier, Academic Press), 84-89. doi: 10.1016/B978-0-12-809633-8.20540-2

Ueda, H., Kaeriyama, M., Mukasa, K., Urano, A., Kudo, H., Shoji, T., et al. (1998). Lacustrine sockeye salmon return straight to their natal area from open water using both visual and olfactory cues. Chem. Sens. 23, 207-212. doi: 10.1093/chemse/23.2.207

Uusi-Heikkilä, S., Wolter, C., Klefoth, T., and Arlinghaus, R. (2008). A behavioral perspective on fishing-induced evolution. Trends Ecol. Evol. 23, 419-421. doi: 10.1016/j.tree.2008.04.006

Vollset, K. W., Krontveit, R. I., Jansen, P. A., Finstad, B., Barlaup, B. T., Skilbrei, O. T., et al. (2016). Impacts of parasites on marine survival of Atlantic salmon: a meta-analysis. Fish Fish. 17, 714-730. doi: 10.1111/faf.12141

Vörösmarty, C. J., McIntyre, P. B., Gessner, M. O., Dudgeon, D., Prusevich, A., Green, P., et al. (2010). Global threats to human water security and river biodiversity. Nature 467:555. doi: 10.1038/nature09440

Wagner, M. A., and Reynolds, J. D. (2019). Salmon increase forest bird abundance and diversity. PLoS ONE 14:e0210031. doi: 10.1371/journal.pone.0210031

Walther, G. R., Post, E., Convey, P., Menzel, A., Parmesan, C., Beebee, T. J., et al. (2002). Ecological responses to recent climate change. Nature 416:389. doi: $10.1038 / 416389 a$
Watson, L. C., Stewart, D. J., and Kretzer, A. M. (2016). Genetic diversity and population structure of the threatened Giant Arapaima in southwestern Guyana: implications for their conservation. Copeia 104, 864-872. doi: 10.1643/CG-15-293

Wilcove, D. S., and Wikelski, M. (2008). Going, going, gone: is animal migration disappearing. PLoS Biol. 6:e188. doi: 10.1371/journal.pbio.0060188

Xue, D. X., Yang, Q. L., Li, Y. L., Zong, S. B., Gao, T. X., and Liu, J. X. (2019). Comprehensive assessment of population genetic structure of the overexploited Japanese grenadier anchovy (Coilia nasus): implications for fisheries management and conservation. Fish. Res. 213, 113-120. doi: 10.1016/j.fishres.2019.01.012

Young, N., Nguyen, V. M., Corriveau, M., Cooke, S. J., and Hinch, S. G. (2016). Knowledge users' perspectives and advice on how to improve knowledge exchange and mobilization in the case of a co-managed fishery. Environ. Sci. Policy 66, 170-178. doi: 10.1016/j.envsci.2016.09.002

Zeng, X., Adams, A., Roffer, M., and He, R. (2019). Potential connectivity among spatially distinct management zones for Bonefish (Albula vulpes) via larval dispersal. Environ. Biol. Fish. 102, 233-252. doi: 10.1007/s10641-018-0826-z

Conflict of Interest Statement: The authors declare that the research was conducted in the absence of any commercial or financial relationships that could be construed as a potential conflict of interest.

Copyright (C) 2019 Lennox, Paukert, Aarestrup, Auger-Méthé, Baumgartner, BirnieGauvin, Bøe, Brink, Brownscombe, Chen, Davidsen, Eliason, Filous, Gillanders, Helland, Horodysky, Januchowski-Hartley, Lowerre-Barbieri, Lucas, Martins, Murchie, Pompeu, Power, Raghavan, Rahel, Secor, Thiem, Thorstad, Ueda, Whoriskey and Cooke. This is an open-access article distributed under the terms of the Creative Commons Attribution License (CC BY). The use, distribution or reproduction in other forums is permitted, provided the original author(s) and the copyright owner(s) are credited and that the original publication in this journal is cited, in accordance with accepted academic practice. No use, distribution or reproduction is permitted which does not comply with these terms. 